\title{
Past climate and vegetation in Southeast Bulgaria - a study based on the late Miocene pollen record from the Tundzha Basin
}

\author{
Dimiter Ivanov ${ }^{*}$ and Maria Lazarova
}

\begin{abstract}
The results of palynological studies on the late Miocene freshwater deposits of the Tundzha Basin (Southeast Bulgaria, SE Europe) are presented. The basin is relatively well known in terms of geology and palaeogeography. The age of sediments in the Tundzha Basin ranges between the late Miocene to the Pliocene, based on mammal and diatom fossils. We carried out a palynological analysis of clayey sediments interlayered with coal beds from four cores and from one outcrop, aiming to obtain information about the composition and the structure of fossil vegetation. The ratios between the main floristic elements and the composition of the fossil flora are analysed and discussed from a palaeoecological point of view. Several main vegetation palaeocommunities were recorded: swamp forests, mixed mesophytic, communities of aquatic plants, and herbaceous palaeocoenoses. The changes in vegetation and in plant diversity are identified. The palaeoclimate analysis indicates a warm temperature climate with high rainfall and mild winter temperatures, without seasonal drier conditions. The early Pontian climate was about $3-4{ }^{\circ} \mathrm{C}$ warmer than today, with rainfalls per year at least $300 \mathrm{~mm}$ higher than today. The results of palaeoecological analysis of the flora and of the quantitative palaeoclimate data show that the climate in the Southeast Bulgaria indicates a climate change towards slight cooling and some drying. This event is consistent with the period of accumulation of the upper, undivided part of the Elhovo Formation.
\end{abstract}

Keywords: Palynology, Palaeobotany, Coexistence approach, Neogene, Tundzha Basin, Bulgaria

\section{Introduction}

Changes in climate and vegetation during the Miocene are the subject of scientific interest which has encouraged studies of fossil floras and palaeoenvironments. After the middle Miocene climatic optimum (MMCO), the Earth climate recorded a progressive cooling trend (Zachos et al. 2001). This reveals a global transformation in biodiversity and ecosystems. For the eastern Paratethys, the emergence of open habitats and the distribution of herbaceous vegetation during the late Miocene characterized the flora and the vegetation turnover (Ivanov et al. 2002, 2007a). The territory of the Balkan Peninsula with its numerous Miocene lakes and swamps served as a key region for the study of the Neogene evolution of flora and vegetation, for

\footnotetext{
* Correspondence: dimiter@bio.bas.bg

Institute of Biodiversity and Ecosystem Research, Bulgarian Academy of Sciences, 23 Acad. G. Bonchev Str., BG-1113 Sofia, Bulgaria
}

the migration routes and for the exchange corridor of many plant species between Central-Eastern Europe and Asia Minor (Meulenkamp et al. 1996; Rögl 1998, 1999; Meulenkamp and Sissingh 2003; Popov et al. 2006; Akgün et al. 2007; Akkiraz et al. 2008; Ivanov et al. 2011; Alçiçek and Jiménez-Moreno 2013; Biltekin et al. 2015; Durak and Akkiraz 2016; Ivanov and Worobiec 2017; Kayseri-Özer 2017; Kayseri-Özer et al. 2017; Yavuz et al. 2017). The territory of Bulgaria apparently provides substantial information for many of these processes, e.g., the survival of a number of palaeotropical species in various refuges and the processes of plant speciation (Palamarev 1989; Palamarev and Ivanov 1998, 2001, 2004; Palamarev et al. 1999; Ivanov 2015).

The spatial distribution of plants and vegetation strongly depends on climatic conditions. Thus, through reconstruction of the vegetation from the past, conclusions can 
be drawn about past climates. Based on this assumption, several quantitative methods have been developed during the last few decades aiming to reconstruct the climate of the past, e.g., the Climate Leaf Analysis Multivariate Programme (CLAMP) (Wolfe 1993), the Coexistence Approach (CA) (Mosbrugger and Utescher 1997; Utescher et al. 2014), the Leaf Margin Analysis (Wilf 1997), the Climatic Amplitude Method (Fauquette et al. 1998), and the European Leaf Physiognomic Approach (ELPA) (Traiser et al. 2005). In this way, many climate reconstructions and a number of local and regional climatic reconstructions have been proposed for the Neogene period (Bertini 2002, 2006; Bruch and Gabrielyan 2002; Ivanov et al. 2002, 2007a, 2007b, 2007c, 2011; Bruch and KovarEder 2003; Fauquette and Bertini 2003; Uhl et al. 2003, 2006, 2007b, 2007a; Bruch et al. 2004, 2006, 2007, 2011; Mosbrugger et al. 2005; Traiser et al. 2005, 2007; Fauquette et al. 2006, 2007; Jiménez-Moreno 2006; Jiménez-Moreno and Suc 2007; Jiménez-Moreno et al. 2007c, 2007a, 2007b, 2008a, 2008b, 2009; Utescher et al. 2007, 2009b, 2009a, 2011a, 2011b, 2013, 2015; Alçiçek and Jiménez-Moreno 2013; Ivanov 2015; Ivanov and Worobiec 2017; Yavuz et al. 2017).

Intensive investigations on the Miocene vegetation and on climate dynamics were performed in the Neogene basins in Bulgaria over the last years, using pollen analysis (e.g., Utescher et al. 2009b; Ivanov et al. 2010, 2011; Hristova and Ivanov 2014; Ivanov 2015; Ivanov and Worobiec 2017). This area plays a key role in the network of palaeoecological studies conducted in different parts of the Balkan Peninsula in relation to SoutheastEuropean Neogene vegetation and flora history, aiming to reveal the chronological succession of the main vegetation phases, the climate changes behind them, species migration and distribution (Akgün et al. 2007; Jiménez-Moreno et al. 2007c, 2007a; Akkiraz et al. 2008; Bozukov et al. 2009; Alçiçek and Jiménez-Moreno 2013; Biltekin et al. 2015; Ivanov 2015; Durak and Akkiraz 2016; Kayseri-Özer 2017; Kayseri-Özer et al. 2017; Yavuz et al. 2017). Nevertheless, there are only few studies in the

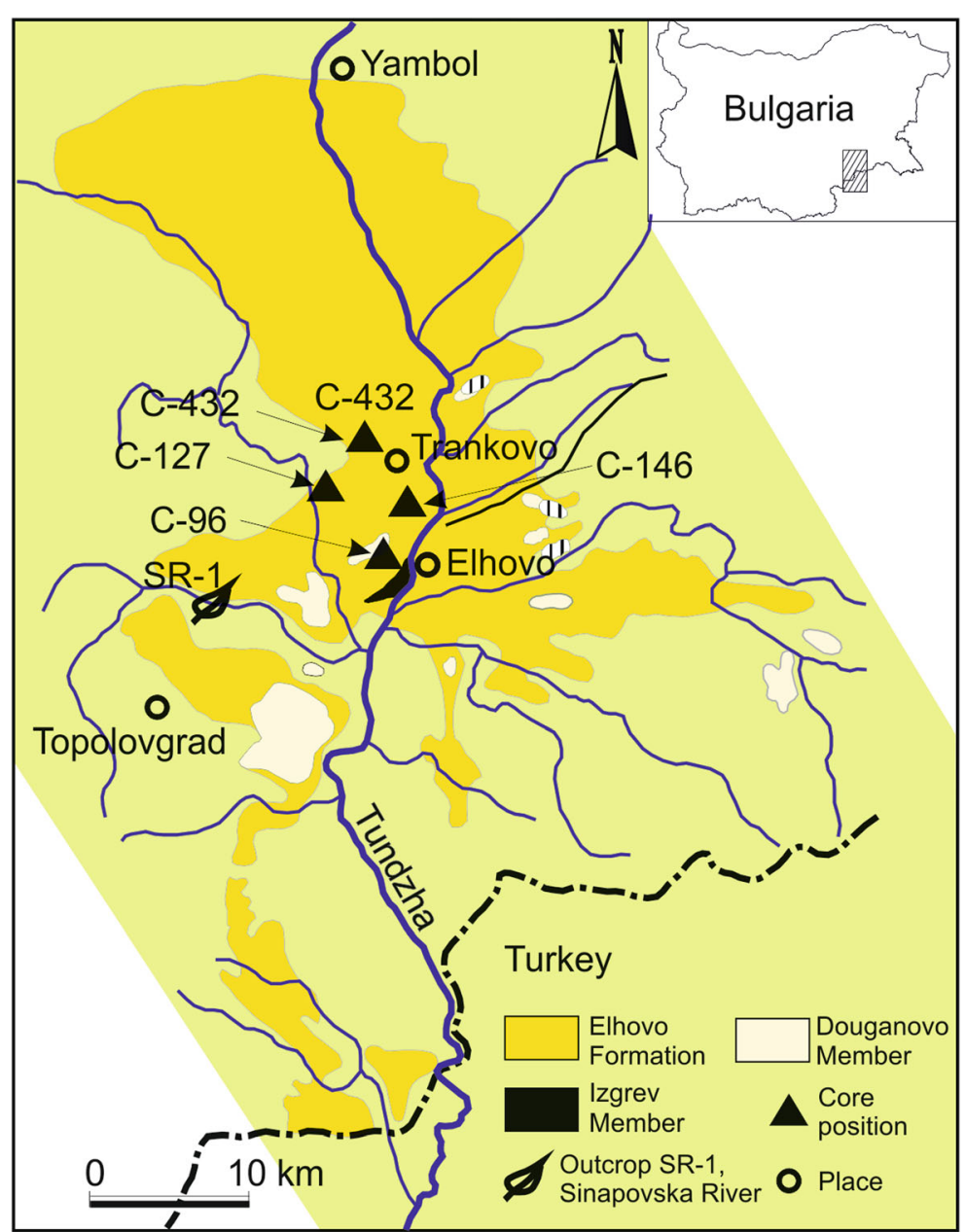

Fig. 1 Geological map of the Tundzha Basin, Southeast Bulgaria (redrawn from Kojumdgieva et al. 1984) 
Southeast Bulgaria on past vegetation and climate (Palamarev and Bozukov 2004; Ivanov and Lazarova 2005; Ivanov et al. 2007b; Ivanov 2004, 2010). The aim of this paper is to present new results on pollen analysis from sediments of the Tundzha Basin and to summarize the available data about the vegetation ecology and climate in this area during the late Miocene.

\section{Geology and palaeogeography}

The Tundzha Basin provides important information on both dynamics of the system of fresh-water basins on Balkan Peninsula (Burchfiel et al. 2000; Nakov et al. 2001) and climate change and vegetation evolution in southeastern part of Europe (Ivanov et al. 2007b, 2010). It occurs in the Southeast Bulgaria (Fig. 1) and in older papers it is also known as the Elhovo-Yambol Basin (Kojumdgieva et al. 1984). The basin has a graben structure, which was generated as a result of movements along faults during the Tortonian (early late Miocene).

The Neogene sediments of the Tundzha Basin are assigned to the Elhovo Formation (Kojumdgieva et al. 1984) with two members (Fig. 1): the Izgrev Member and the Duganovo Member, and one undivided part (Prustnik Limestone Formation; access to Angelova et al. 1991). It is represented by an irregular alternation of claystone, sandstone and rare conglomerates. The thickness of the Elhovo Formation is ca. $150-200 \mathrm{~m}$, but locally it reaches up to $300 \mathrm{~m}$. Within these deposits, large lenses of gray and black clays, diatomite clays and lignites are grouped within the Izgrev Member, which locally occurs in the middle part of the basin (Fig. 1). The total thickness of the Izgrev Member reaches up to $40 \mathrm{~m}$, with three main coal seams, each of them with a thickness varying from $3 \mathrm{~m}$ up to $8 \mathrm{~m}$.

The lignite seams accumulated in a rheotrophic, lowlying mire. A vegetation rich in decay resistant conifers dominated in the Elhovo Formation together with mesophytic angiosperm species. The peat accumulation occurred in an environment subject to a low subsidence rate, in which the woods were sustained severe mechanical destruction prior to the burial. Peat accumulation was terminated by a major flooding event, expressed by a short-lived lake (Zdravkov et al. 2007). The Elhovo Formation is unconformably overlain by a few meters of the Pleistocene-Holocene sediments.

The vertebrate fauna recorded to the upper part of the Elhovo Formation (Kojumdgieva et al. 1984; Nikolov 1985) reveals a Pontian (=late Messinian)-Pliocene age (MN 13-14). The results of the diatom analysis (Temniskova-Topalova et al. 1996; Temniskova-Topalova and Ognjanova-umenova 1997) confirmed the late Miocene age (Pontian age for Elhovo Formation). The lithological and facies characters and the specific cyclicity of the sediments of the Tundzha Basin gave grounds to some authors to define these sediments as analogous to the
Neogene sediments of the Upper Thracian Basin (Dragomanov et al. 1984). However, similar correlations were confirmed neither by biostratigraphic data, nor by detailed sedimentological studies. Even more, significant differences occur in the nature of sedimentation processes in the two basins, with specific periods of sedimentation interruption and denudation surfaces.

The sediments of the Elhovo Formation are deposited in alluvial, fluvial and locally lacustrine-marshy environments (Nakov et al. 2001). As a result of extensive tectonic movements at the beginning of the late Miocene, a number of freshwater pools appeared in the Balkans, including the Tundzha Basin. During the Maeotian, two low areas were formed: Yambol and Elhovo (Savov 1983). The initial alluvial sedimentation had been predominantly replaced by lake and swamp environments (Izgrev Member). Gradually, the basin was filled, and at the end of the Pontian and the early Pliocene, the alluvial sedimentation was restored.

\section{Material and methods}

\subsection{Studied sections}

Fossil material has been collected and studied from four cores in the central part of the Tundzha Basin: C-96, C-146, C-127 and C-432 (Figs. 1 and 2). The outcrops of the Neogene sediments of the Tundzha Basin are very scarce and they expose only the topmost intervals with sands and sandstones. The drilled cores in the area provide the best material for studies and analyses. A basic profile of the present study is the core C-432, near the village of Trankovo, north of the town of Elhovo (Fig. 1). This profile crosses the sediments of the Izgrev Member of the Elhovo Formation. Samples of black and greyish clays, lignite clays and diatomaceous clays are analyzed. The total thickness of the studied profile is about $40 \mathrm{~m}$. In addition, materials from the other three cores located north-northwest of the town of Elhovo, close to the core C-432, were analyzed, namely cores C-96, C-146 and C-127 (Figs. 1 and 2).

Twenty-eight samples from the upper part of the Elhovo Formation from three outcrops were collected for pollen and spores analyses: 1) the outcrop in the abandoned quarry in Prastnitsata, $200 \mathrm{~m}$ west of the Izgrev village, Elhovo district (Kojumdgieva et al. 1984), including about $1.5 \mathrm{~m}$ greenish clayey alleurites with limestone and green muds, 6-7 $\mathrm{m}$ white and yellowish fine-grained sands with layers of medium to coarse grain sands (six samples); 2) the outcrop along the road from Elhovo to Golyam Manastir village (SR-1), close to the bridge over the Sinapovska River (18 samples); and, 3) the outcrop Hanovo on the right bank of the Tundzha River between the Hanovo and Tenevo villages, including cross-bedding sands with thin layers of sandy clays 


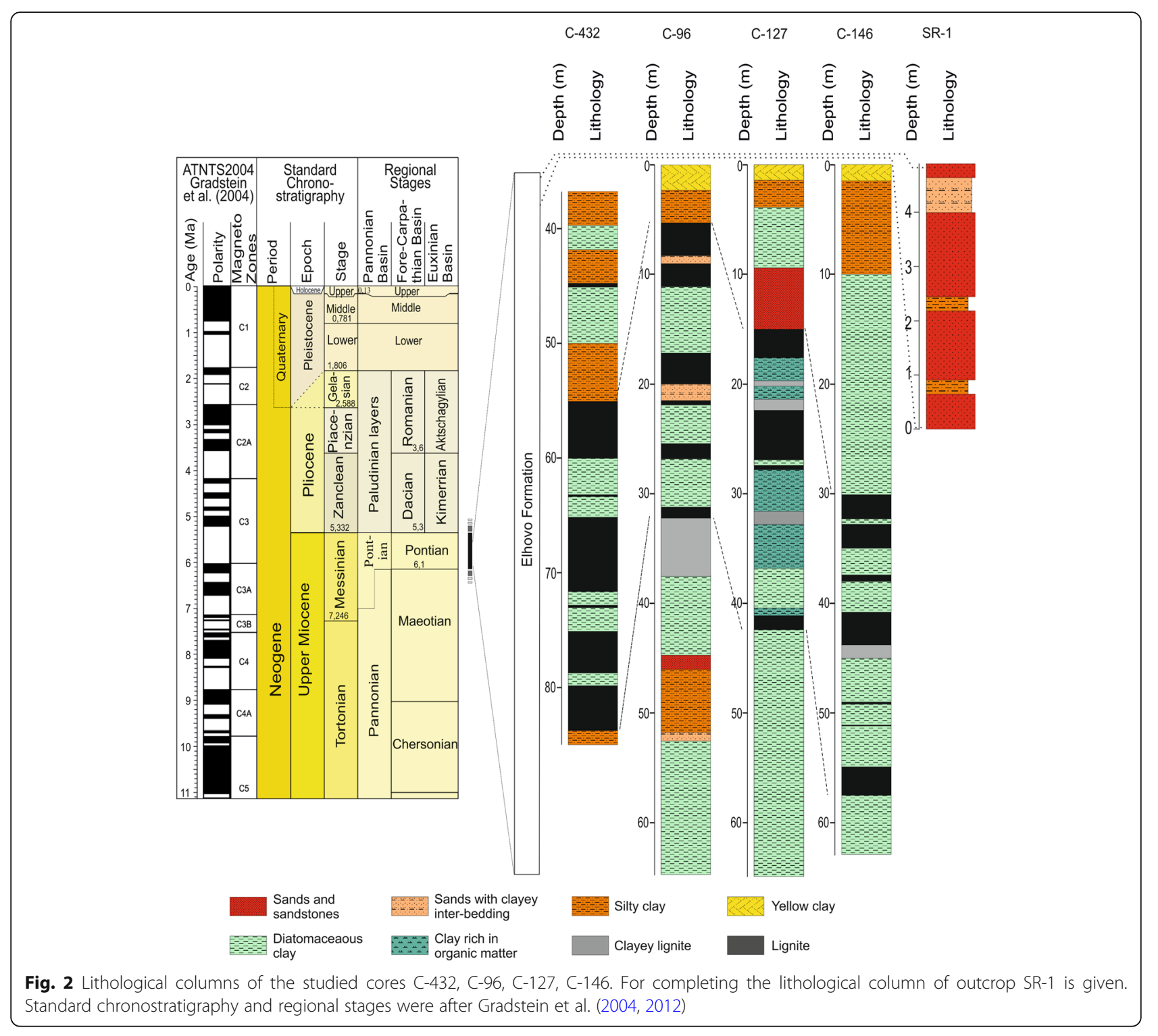

(four samples). Samples of these outcrops proved to be barren, except for some of the samples of the outcrop SR-1 (Sinapovska River outcrop).

The profile near Sinapovska River (SR-1) includes about $5 \mathrm{~m}$ of sandstones with three layers of about $0.5 \mathrm{~m}$ of green to purple aleuritic clays, followed by $5-10 \mathrm{~m}$ of cross-bedded sands (for details see Ivanov et al. 2007c). Leaf imprints and pollen have been found in the clay layers. The sedimentological analysis of the flora-bearing sediments (Ivanov et al. 2007c) explains the conditions for the accummulation of sediments and for the preservation of the fossil material. Good preservation of plant debris is related to the relatively rapid sedimentation (accumulation) rate of the alluvial clay material in which they were deposited. This material underwent significant compaction due to the pressure of the overlying sediments.
But the high sedimentation rate is inappropriate for the accumulation of sufficient pollen, which is why the established pollen complexes are comparatively pure.

The total number of studied samples from the Tundzha Basin is 64: 27 were barren, but 35 from four cores and two from the outcrop SR-1 contained enough pollen for study.

Tracing the changes in the percentage values of the different pollen type curves permitted the identification of pollen zones in the investigated cores. Differentiation of the pollen zones is based on sediments with a specified fossil content, or specific palaeontological characters (characteristic pollen complexes, type and frequency of palynomorphs), which distinguish them from the neighbouring sediments (Gordon and Birks 1972). The presented pollen zones for each core were regarded as Local Pollen Zones 
(LPZ) indexed by letters and digits. The palynological subdivision was applied only for the core C-432, which contains enough samples for correlation.

\subsection{Methods for vegetation and climate reconstructions}

The principles of autecology were used for the reconstruction of vegetation, as well as the data on ecological requirements of the nearest analogues of the fossil taxa. As many Neogene European floras, the flora of the Tundhza Basin includes taxa whose nearest living relatives (NLR) now grow in distant areas, e.g., East Asia and North America. The palaeocoenoses were reconstructed with the help of autecological analysis, assuming that the ecological requirements of fossil taxa are similar to those of their recent analogues; taxa with similar ecological and edaphic requirements were grouped and the main palaeocommunities were identified.

Charts showing the results of the pollen analyses are illustrated by two types of pollen diagrams: detailed and synthetic. The first diagrams include all identified plants and show their individual presence. In the second type of diagrams, the plants were ordered into ecological groups following Suc (1984) and Jiménez-Moreno et al. (2005) and they provide information for the general trends in

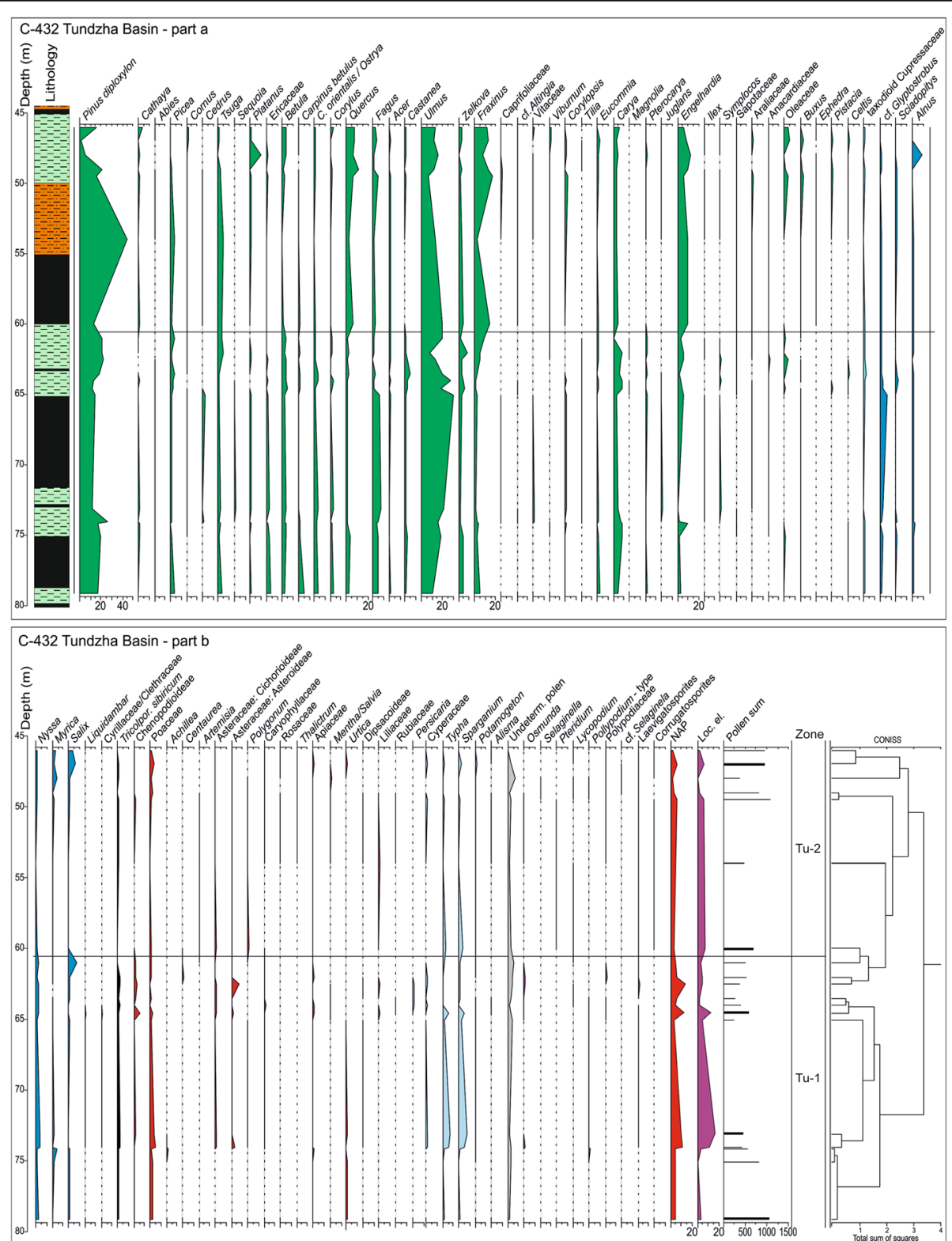

Fig. 3 a Spore-pollen percentage diagram of core C-432, Tundzha Basin (part a); b Spore-pollen percentage diagram of core C-432, Tundzha Basin (part b) 
vegetation change. The synthetic pollen diagram was plotted with pollen taxa arranged in different groups on the basis of ecological criteria to clearly show the temporal changes in vegetation.

The groups used are the following (Nix 1982):

Mega-mesothermic (subtropical) elements: "taxodioid" Cupressaceae pollen, Taxodium-type, Symplocos, Engel hardia, Platycarya, Myrica, Sapotaceae, Distylium, Ha mamelis, Corylopsis, Castanea-Castanopsis type, Cyrilla ceae-Clethraceae, Reevesia, Theaceae, Alangium, Chloranthaceae, Parthenocissus, Araliaceae, Arecaceae and others;

Cathaya: pollen of Cathaya sp.;

Mesothermic elements: (Quercus, Carya, Pterocarya, Carpinus betulus, Carpinus orientalis, Ostrya, Parrotia, Eucommia, Juglans, Zelkova, Ulmus, Tilia, Acer, Liquid ambar, Alnus, Salix, Populus, Rhus, Celtis, Platanus, Nyssa, Ilex, Lonicera, Caprifoliaceae, Vitaceae, Fraxinus, Betula, Sequoia-type, Fagus, Hedera, Ilex, Tilia, etc.;

Pinus + Pinaceae: Pinus diploxylon type and undetermined Pinaceae pollen;

Mid-altitude trees (Meso-microthermic elements): Tsuga, Cedrus, Sciadopitys;

High-altitude trees (microthermic elements): Abies, Picea, Keteleeria;

Cupressaceae: Cupressus-Juniperus-type and/or pollen irrespective of environmental interpretations, including unspecified pollen grains;

Xerophytes: xerophyte taxa e.g. Quercus ilex-cocciferatype, Olea-type (Oleaceae), Caesalpiniaceae, Pistacia, Rhus and others;

Herbs: Poaceae, Amaranthaceae, Asteraceae-Asteroid eae, Asteraceae-Cichorioideae, Centaurea, Plantago, Brassicaceae, Lamiaceae, Valerianaceae, Polygonaceae, Knautia (Dipsacoideae), Rosaceae, Malvaceae, Geran iaceae, Erodium, Caryophyllaceae, etc.;

Steppe elements: Artemisia, Ephedra.

The palaeoclimate reconstructions in this work are based on the Coexistence Approach (CA) (Mosbrugger and Utescher 1997; Utescher et al. 2014), and based on the assumption that climatic requirements of the fossil plants for environmental conditions are similar to those of their recent analogues. It should be noted that the Coexistence Approach uses only the presence or absence of taxa, without analyzing their relative frequency. Tests have shown that the approach yields good results when applied to fossil floras with more than ten taxa with a known contemporary analogue. The approach is valid for various types of fossils: leaves, fruits and seeds, spores and pollen grains. This method permits to analyze also carpological data and to compare the two types of fossil associations. This method provides a robust palaeoclimatic proxy although its reliability has been questioned by some authors (Grimm and Denk 2012; Grimm et al. 2016). A lot of studies were undertaken for testing different climate reconstruction methods (CAMethod, LMA, CLAMP, ELPA, etc.), which emphasized some differences in the results when comparing the CA and other proxies. But in most cases, similar results were obtained (Bruch et al. 2002; Uhl et al. 2003; Yang et al. 2007; Jacques et al. 2011, 2014; Xing et al. 2012; Bondarenko et al. 2013). The results are consistent with respect to global climate reconstructions, and in general they are consistent with the data obtained from a large variety of other proxies, for example isotope geochemistry, small mammals or other independent palaeoclimatic approaches.

The Palaeoflora Database (Utescher and Mosbrugger, 1990-2018) has been used for palaeoclimatic reconstructions. The graphic presentations of palaeoclimate results are illustrated by the respective figures, where the coexistence intervals (CA-intervals) for each pollen spectrum (=local pollen flora) are represented by four parameters. Besides the respective CA-intervals, the graphics also show a curve of the CA mean values. This curve does not mean that these are the most probable values (the values of the respective climate parameter could remain within the boundaries of the range), but they illustrate approximately the changeability of climate and the dynamics of climate values over time (Pross et al. 2000; Ivanov et al. 2002).

\section{Results}

\subsection{Palynological subdivision of the Elhovo formation}

Core C-432 (Fig. 3)

Local pollen zone $\mathrm{Tu}-1$

Ulmus - Betula - Carya

Age: late Miocene.

Distribution: 79.0-61.0 m.

The core is marked by high values of the Ulmus pollen, which is represented by values ranging mainly in the range of $13 \%-20 \%$ and with a maximum of $29.8 \%$ at $65.0 \mathrm{~m}$. The quantity of Carya pollen is $4 \%-9 \%$, which are the highest values in the core. The Betula pollen is also represented with higher values $(3 \%-5 \%)$ in this part of the profile. Fagus is represented with higher values in the lower part of the zone $(3.9 \%-7.4 \%)$, and is below $1 \%$ and marked by a sharp drop in the upper part (interval 64.5-61.0 m). Similar dynamics of the quantitative values are characteristic for inaperturate pollen referred to Glyptostrobus $3 \%-6 \%$ at the base and a drop to about $1 \%$ in the upper part. Carpinus orientalis/Ostrya type, Ericaceae, Nyssa, Poaceae, Typha, Sparganium and Tricolporopollenites sibiricum are also registered with higher values. Pinus diploxylon type is represented by constant values ranging 
in narrow range between $17 \%$ and $20 \%$, with single deviations from them, e.g., $11.3 \%$ at $73.0 \mathrm{~m}$ or $26.1 \%$ at $74.0 \mathrm{~m}$. Cathaya has low values not exceeding $1.5 \%$. The pollen of herbs is low (less than 1\%), with the exception of Poaceae, Asteraceae, partially Amaranthaceae: Chenopodioideae. Higher values for these three pollen types trigger higher NAP (Non-Arboreal Pollen grains) values, reaching a percentage of $13.1 \%$, which is the maximum for the entire profile. Local elements also have a broader involvement in the pollen spectrum of this zone, reaching maximum value of $15.6 \%$ at $73.0 \mathrm{~m}$.

Local pollen zone Tu-2

Engelhardia - Quercus - Fraxinus

Age: late Miocene.

Distribution: 60.0-46.0 m.

Quercus records higher values in this part of the profile. While in the previous zone it is discovered in quantities of about $2 \%$, in this zone its values vary between $6 \%$ and $11 \%$. The change in the Engelhardia is similar, after a relatively poor presence in the $\mathrm{Tu}-1$ zone $(2 \%-5 \%)$, the participation rate increased to $8 \%-10 \%$ and even $11.8 \%$ (maximum value for the whole profile registered at $48 \mathrm{~m}$ ). The most significant is the increase in the participation of Fraxinus: it reaches up to $12 \%-16 \%$ from $2 \%-5 \%$. Parallel to this, Tsuga values increase up to $4 \%$, and also Corylopsis, but less pronounced. Oleaceae (up to 4.7\%), Buxus (up to $2.6 \%$ ) and Pistacia (up to $1 \%$ ) are shown at the top of the higher-value zone. Platanus pollen is below $1 \%$ across in the profile, but at $48.0 \mathrm{~m}$ it has a peak of $9.6 \%$. At the same depth $(48.0 \mathrm{~m})$, Alnus, whose pollen in the rest of the profile has a constant participation of $1 \%-2 \%$, also shows its maximum percentage. In the range of 48.0-46.0 $\mathrm{m}$, the Myrica (up to 3.6\%) and Salix (up to 6.3\%) were recorded. Lower values in this zone are registered for Betula, Fagus, Ulmus and Carya, which were predominant in the previous zone. Pollen of herbaceous plants (NAP) is also presented with lower values. The local elements with reduced pollen spectra in this pollen zone are Typha and Sparganium. Pinus pollen reaches a peak at $54.0 \mathrm{~m}$ (45\%), followed by a decreasing trend. Cathaya, as well as in the Tu-1 zone, is low at $1.0 \%-1.5 \%$.

The pollen diagrams of the cores C-96, C-127 and C146 are not divided into pollen zones due to the small number of studied samples (four to six in each core). The analysis of pollen content and the quantification of fossil palynomorphs show a similarity to the local pollen zone (LPZ) Tu-2 on core C-432. The major pollen types found in the cores C-96, C-127 and C-146 are of similar values in all pollen spectra. Quercus pollen records high values ranging from $6 \%$ to $11 \%$. In this respect, the proximity to the quantitative coverage of this type of pollen is almost identical to its participation in the LPZ Tu-2. Ulmus has variable values, with about $2 \%$ in most samples up to a maximum of $12.5 \%$. With similar values, this type of pollen is recorded in the upper parts of the LPZ Tu-2. Similar values are represented by Tsuga and Picea, for which values of $1 \%-2 \%$ were established in four profiles. Similar quantities are observed in the pollen of Betula, Fagus, Oleaceae, Pterocarya, Carya, Engelhardia, Alnus, Salix, and Myrica ranging from 1\%$2 \%$ to $3 \%-4 \%$.

The main differences in both profiles refer to Pinus pollen. Pinus diploxylon-type in LPZ Tu-2 has a quantitative value close to the core C-96 (except the maximum at $54.0 \mathrm{~m}$ ), followed by a decreasing trend observed in both profiles. The more significant is the presence of Cathaya, which in the LPZ Tu-2 was presented with lower values $(1.0 \%-1.5 \%)$, and only in the pollen spectrum of $46.0 \mathrm{~m}$ was registered with higher values $(3.6 \%)$. In the core C-96, this type of pollen is registered with higher values of $11 \%-17 \%$, which in the upper part of the section reduced to $5 \%$. Higher values may be explained partly by local features in the structure of vegetation, suggesting a greater involvement of Cathaya in the pollen rain. Another possibility is related to a discrepancy in stratigraphic levels, e.g., the cut-out interval from the core is a later stage of the LPZ Tu-2, at the end of which higher values of this pollen type were recorded. The lack of other fossils, lithological and stratigraphic data makes the correlation of the two cores less reliable.

The pollen flora from the "Sinapovska River" outcrop (SR-1) differs significantly from the flora found in the sediments of the Izgrev Member of the Elhovo Formation. The profile includes layers of greenish to violet aleuretic clays, which refer to the uppermost levels of Elhovo Formation and correspond to a later stage in the development of the flora in the area. A characteristic feature of the pollen flora is the significant involvement of pollen from herbaceous plants and the lack of representatives of spore plants. Herbaceous plants are subject to significant taxonomic diversity and to a high percentage participation, e.g., Amaranthaceae: Chenopodioideae (11.6\%), Asteroideae (8.5\%), Poaceae (7.1\%), Dipsacoideae (Caprifoliaceae) (5.4\%), and Artemisia (2.7\%). The composition of the spore-pollen complex differs significantly from the pollen complexes of the studied samples from cores C-432, C-96, C-127 and C-146. At the same time, the low content of pollen in the studied samples makes the separation of an independent pollen zone in the outcrop Sinapovska River (SR-1) uncertain.

\subsection{Fossil flora and vegetation of the Tundzha Basin}

The pollen analysis of the sediments of the Tundzha Basin (the Izgrev Member of the Elhovo Formarion and the upper undivided part of the Elhovo Formation) reveals the characters and the peculiarities of the fossil flora and vegetation during their accumulation. The total 
Table 1 Taxonomic composition of the fossil pollen flora from the Tundzha Basin

\begin{tabular}{|c|c|}
\hline Taxa & Taxa \\
\hline Abies sp. & Lycopodium sp. \\
\hline Acer sp. & Magnolia sp. \\
\hline Achillea sp. & Mentha/Salvia \\
\hline Alisma sp. & Myrica sp. \\
\hline Alnus sp. & Nuphar sp. \\
\hline Amaranthaceae: Chenopodioideae & Nymphaeaceae \\
\hline Anacardiaceae & Nyssa sp. \\
\hline Apiaceae & Oleaceae \\
\hline Araliaceae & Osmunda sp. \\
\hline Artemisia sp. & Parrotia sp. \\
\hline Aster type & Persicaria sp. \\
\hline Asteraceae & Picea sp. \\
\hline Asteraceae: Asteroideae & Pinaceae indet. \\
\hline Asteraceae: Cichorioideae & Pinus diploxylon-type \\
\hline Betula sp. & Cathaya sp. \\
\hline Brassicaceae & Trifolium sp. \\
\hline Buxus sp. & Pistacia sp. \\
\hline Caprifoliaceae: Caprifolioideae & Plantaginaceae \\
\hline Caprifoliaceae: Dipsacoideae & Platanus sp. \\
\hline Carpinus betulus type & Platycarya sp. \\
\hline Carpinus orientalis/Ostrya type & Poaceae \\
\hline Carya sp. 1 and sp. 2 & Polygonum sp. \\
\hline Caryophyllaceae & Polypodiaceae \\
\hline Castanea sp. & Polypodiosporites sp. \\
\hline Castanopsis sp. & Potamogeton sp. \\
\hline Cedrus sp. & Pteridium sp. \\
\hline Celtis sp. & Pteridophyta \\
\hline Centaurea sp. & Pterocarya sp. 1 and sp. 2 \\
\hline cf. Altingia & Quercus sp. 1 and sp. 2 \\
\hline cf. Glyptostrobus & Ranunculaceae \\
\hline Cornus sp. & Rosaceae \\
\hline Corrugatosporites sp. & Rubiaceae \\
\hline Corylopsis sp. & Salix sp. \\
\hline Corylus sp. & Sapotaceae \\
\hline Cupressaceae (Cupressus-Juniperus-type) & Sciadopitys sp. \\
\hline Cyperaceae & Selaginella sp. \\
\hline Cyrillaceae/Clethraceae & Sequoia-type sp. \\
\hline Echinatisporis sp. & Sparganium sp. \\
\hline Engelhardia sp. 1 and sp. 2 & Symplocos sp. \\
\hline Ephedra sp. & Tamarix sp. \\
\hline Equisetum sp. & 'Taxodioid' Cupressaceae \\
\hline cf. Euphorbia & Thalictrum sp. \\
\hline Ericaceae & Tilia sp. \\
\hline
\end{tabular}

Table 1 Taxonomic composition of the fossil pollen flora from the Tundzha Basin (Continued)

\begin{tabular}{ll}
\hline Taxa & Taxa \\
\hline Eucommia sp. & Tricolporopollenites sibiricum \\
Fabaceae & Tsuga canadensis-type \\
Fagus sp. & Tsuga heterophylla-type \\
Fraxinus sp. & Tsuga sp. \\
Hedera sp. & Typha sp. \\
Humulus/Cannabis type & Typha/Sparganium \\
Ilex sp. & Ulmus sp. \\
Juglans sp. 1 and sp. 2 & Urtica sp. \\
cf. Keteeleria & Verrucatosporites sp. \\
Laevigatosporites & Viburnum sp. \\
Liliaceae & Vitaceae \\
Liquidambar sp. & Zelkova sp. \\
Lonicera sp. & Botryococcus sp. \\
\hline
\end{tabular}

composition of the fossil flora from four cores and the outcrop SR-1 includes 114 taxa (Table 1; Plates 1, 2 and 3 ). The basic floristic diversity of the relatively rich Tundzha palaeoflora is due to arboreal plants, a characteristic feature of the late Miocene flora. They are represented by 87 taxa from 50 families (among them the tree and shrub species predominate as 60 taxa, and the grasses are 27 taxa), the Gymnosperms are registered with 16 pollen taxa, and the spores plants are with 12 species. The Pinaceae pollen has the highest values among the trees, with the Pinus diploxylon-type predominant in the cores C-432, C-127 and C-146 and the Cathaya is more frequent in the core C-96. Picea, Abies, Tsuga, Cedrus, Sequoia-type, and Cupressaceae (Cupressus-Juniperustype) are present in small amounts, usually less than $3 \%$. The families Fagaceae, Juglandaceae, Betulaceae, Asteraceae, Ulmaceae, Hamamelidaceae and Oleaceae are present with higher diversity among angiosperms. Quercus, Ulmus, Fraxinus, Fagus, Engelhardia and Carya are the most abundant among them. The percentage of most taxa varies within a relatively narrow range, mainly between $1 \%-5 \%$, and refers to Betula, Corylus, Carpinus, Acer, Tilia, Castanea-Castanopsis-type, Corylopsis, Eucommia, Pterocarya and others.

The thermophillous elements are relatively limited in the composition of the flora in terms of their floral diversity. Grass plants are poorly represented in quantitative terms, although they are covered with 27 taxa, which is about a fifth of the palaeoflora diversity. The pollen of wood and shrub components (AP) is predominant. This implies the dominance of the forest-type vegetation in the areas around the basin. This does not apply to the pollen flora from the outcrop of Sinapovska River, where the grass component is much better represented. 

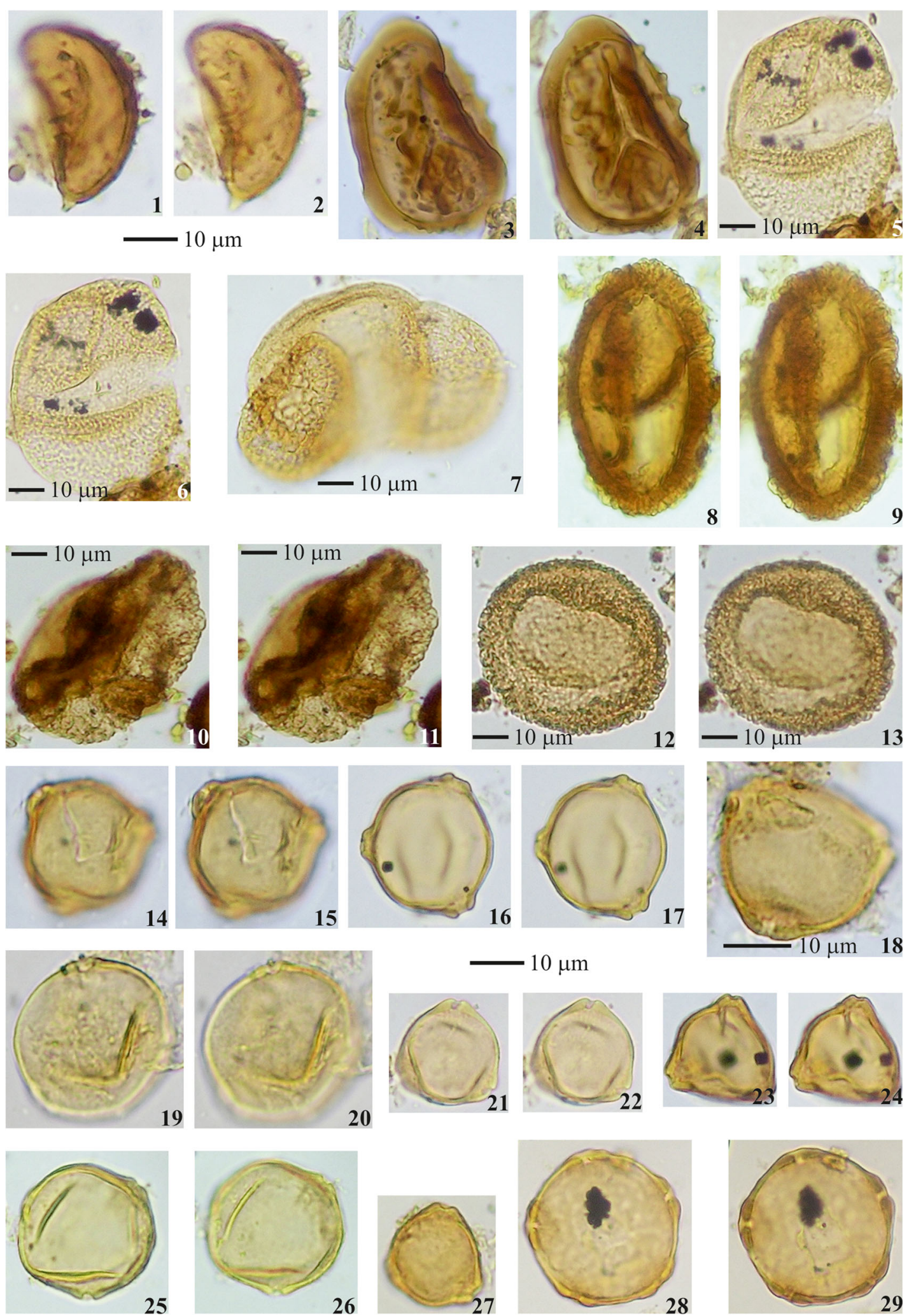

Plate 1 Selected spores and pollen from the late Neogene of the Tundzha Basin. 1, 2 - Polypodiaceae/Thelypteridaceae (Laevigatosporites); 3, 4 Pteridaceae (Polypodiaceoisporites cf. gracillimus Nagy); 5, 6 - Cathaya sp.; 7 - Abies sp.; 8, 9 - Tsuga sp.; 10, 11 - Tsuga canadensis type; 12,13 - Tsuga heterophylla type; 14, 15 - Betula sp.; 16, 17 - Betula sp.; 18, 23, 24 - Myrica sp.; 19, 20 - Carpinus betulus type; 21, 22, 27 - Corylus sp.; 25, 26 - Carpinus orientalis type; 28,29 - Ulmus sp. Scale bars $=10 \mu \mathrm{m}$ 
An interesting feature of the palaeoflora is the morphological variability of the pollen of the Juglandaceae family, observed in all recorded genera. In the case of genus Engelhardia (Pl. 3: 1-9) the variability can be considered within the range of the natural variation of the morphological features as it shows smooth transitions without distinct differences in grain outline and in morphometric characteristics. This pollen type can be assumed to be within the range of the variability of Engelhardia wallichiana-type (Ivanov 2004). The pollen illustrated on Pl. 3-10 and Pl. 3-11 is morphologically close to Engelhardia spicata-type, and more specifically to the pollen of modern species of E. rigida Blume and E. spicata Blume.

Two morphotypes were found in the Carya pollen ( $\mathrm{Pl}$. 2: 29-33), which differ in size of pollen grains and thickness of the exine. The pollen of Pterocarya is also represented by two pollen types (Pl. 3: 14 and 15), with a major difference between them in the shape of apertures and in the exine thickness, the first closer to the modern species Pterocarya pterocarpa (Michx.) Kunth. (Pl. 3-14) and the second closer to Pterocarya serrata Schneider (Pl. 3-15).

Exine thickness, pollen grain outlines and aperture shape are the diagnostic characters allowing the separation of two morphotypes in the fossil pollen of Juglans (Pl. 3: 12 and 13), corresponding to the artificial species Juglandipollis juglandoides Kohlman-Adamska (Pl. 3-12) and Juglandipollis maculosus (Pot.) Kohlman-Adamska (Pl. 3-13).

The palaeoflora from the outcrop SR-1 has a more limited floristic composition, as the palynomorphs are poorly preserved due to taphonomic reasons (see above Chapter 4.1.). The high sedimentation rate at which fossil deposition is formed explains the poor pollen content of the recorded fossil complexes (Ivanov et al. 2007c). The palaeobotanical studies on the composition of the macroflora include mainly the results of the leaves from the outcrop SR-1 (Palamarev and Bozukov 2004). The macroflora is represented by 33 species belonging to 16 families. Scarce palaeofloristic data are also reported for carpoids from the Elhovo Formation (including the Izgrev Member) - Potamogeton, Phelodendron, Polycnemum, Portulaca, Arenaria and Chenopodium (Palamarev 1990; Mai and Palamarev 1997). A total of 35 genera were found in the macroflora composition, and 11 of them were confirmed by palynomorphs. 64 species are reported in the present study as new fossil taxa for the studied area.

The data obtained from the four cores (Figs. 3, 4, 5 and 6) show that the mesophytic forest communities played a key role in the formation of the natural vegetation cover in the studied area during the sediment deposition of the Izgrev Member. Mixed mesophytic forests occupied vast territories in the plain and in the lowlands surrounding the basin. A dominant role in their structure was played by representatives of Quercus, Ulmus, Fraxinus, Fagus, Engelhardia and Carya. The structure of the mesophytic forests was not constant in time and space, and at certain stages, species of different genera were dominant. This is emphasized by the changes in the quantitative involvement of these major pollen types in pollen records, due to the dynamics of vegetation in time. The spatial differentiation of vegetation and the prevalence of different plant types in the areas along water bodies explain the differences in quantitative values of the dominant taxa in the four cores. From a taphonomic and palaeoecological point of view, the mixed mesophytic forests inhabited a natural polytope complex, with a variety of lowland and low hilly terrain, crossed by a complex river network and marked by the presence of large lakes or swamps.

The composition of the mixed mesophytic forest communities varied, and besides the families already mentioned, the representatives of Magnolia, Betula, Corylus, Carpinus, Fagus, Acer, Tilia, Castanea, Corylopsis, Parrotia, Eucommia, Pterocarya, Juglans, Ilex, Buxus and others participate in their structure. Thermophilous plant species of the genera and families Platycarya, Engelhardia, Symplocos, Sapotaceae, and Araliaceae are also present in pollen spectra with varying frequencies in sediments of different age and position. Of these, only the representatives of the Engelhardia probably had a dominant role at certain stages of vegetation development. The reasons for such an assumption are provided by the data dealing with quantitative values of this genus illustrated in Figs. 3, 4, 5 and 6.

The variegated palaeofloristic composition of mixed mesophytic forest communities suggests the presence of vertical differentiation of palaeoflora and of palaeocenoses and the existence of a belt of mountain forest palaeocenoses. The components involved in the construction of mountain palaeocenoses include representatives of the genera Tsuga, Abies, Keteleeria, Picea, Cedrus and Cathaya, generating mixed communities with the participation of Betula, Fagus, Acer and Ericaceae.

The vertical differentiation of vegetation has been expressed in mountain systems located remote from the Tundzha Basin. The low values of the representatives of these communities (Figs. 3, 4, 5 and 6) support such conclusions. This is particularly emphasized by the synthesized pollen diagrams, where the meso-microthermal groups (hill and low-mountain communities) and the microthermal elements (involved in the structure of high-mountain forest ecosystems) are presented at values around and below 5\% (Figs. 7, 8, 9 and 10). These data support the idea that in the region of present-day southeastern Bulgaria, which is predominantly flat and with low mountains, the main mountain ecosystems were relatively distant from the place of pollen deposition. 

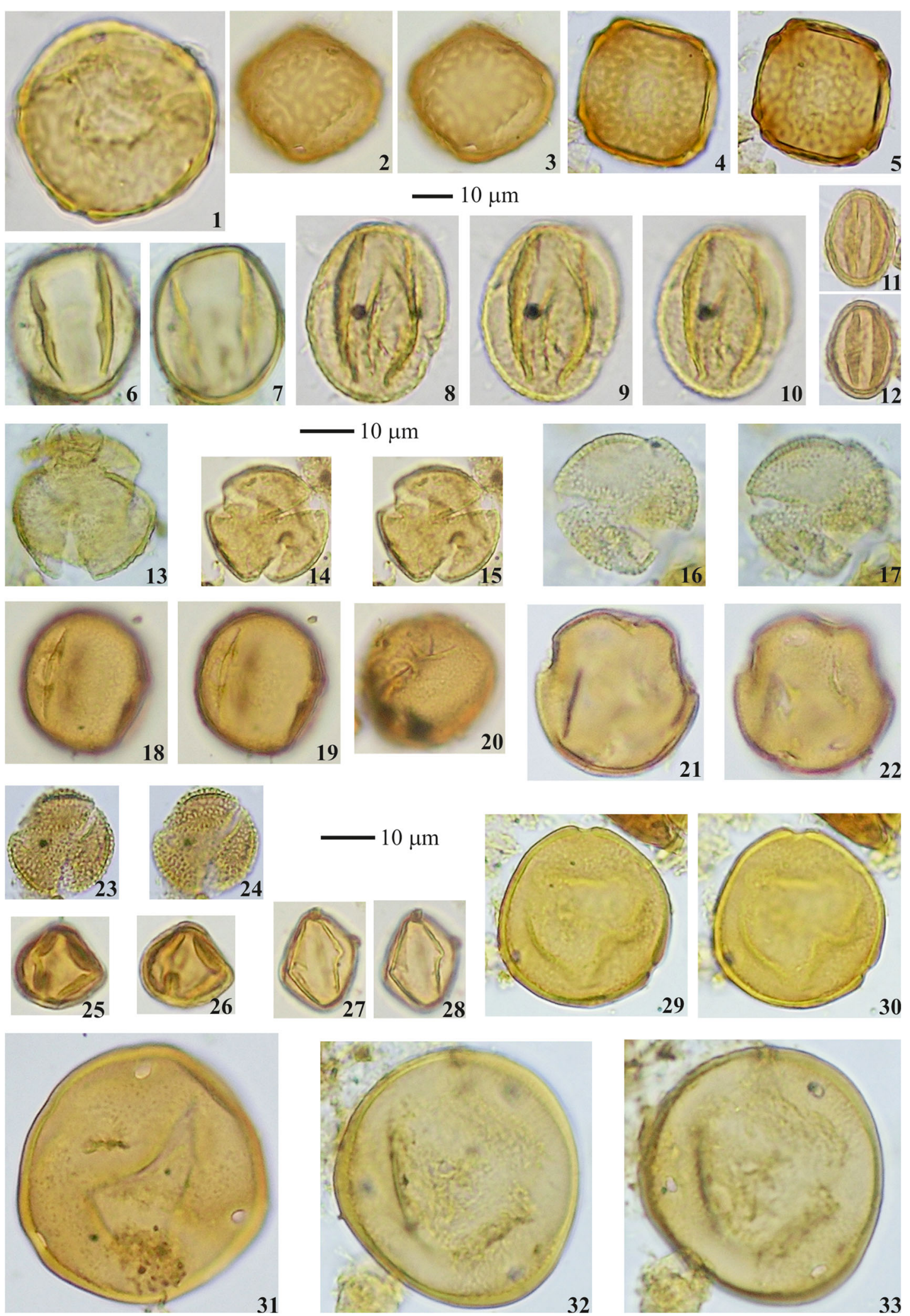

Plate 2 Selected spores and pollen from the late Neogene of the Tundzha Basin. 1 - Ulmus sp.; 2-5 - Zelkova sp.; 6, 7 - Eucommia sp.; 8-10 Quercus sp. 1; 11, 12 - Quercus sp. 2; 13-15 - Quercus sp. 1 (Polar view); 16, 17 - cf. Parrotia; 18-20 - Fagus sp.; 21, 22 - Liquidambar sp.; 23, 24 Salix sp. (Polar view); 25, 26 - Cyrillaceae/Clethraceae; 27, 28 - cf. Cyrillaceae; 29, 30 - Carya sp. 1; 31-33 - Carya sp. 2. Scale bars = $10 \mu \mathrm{m}$ 

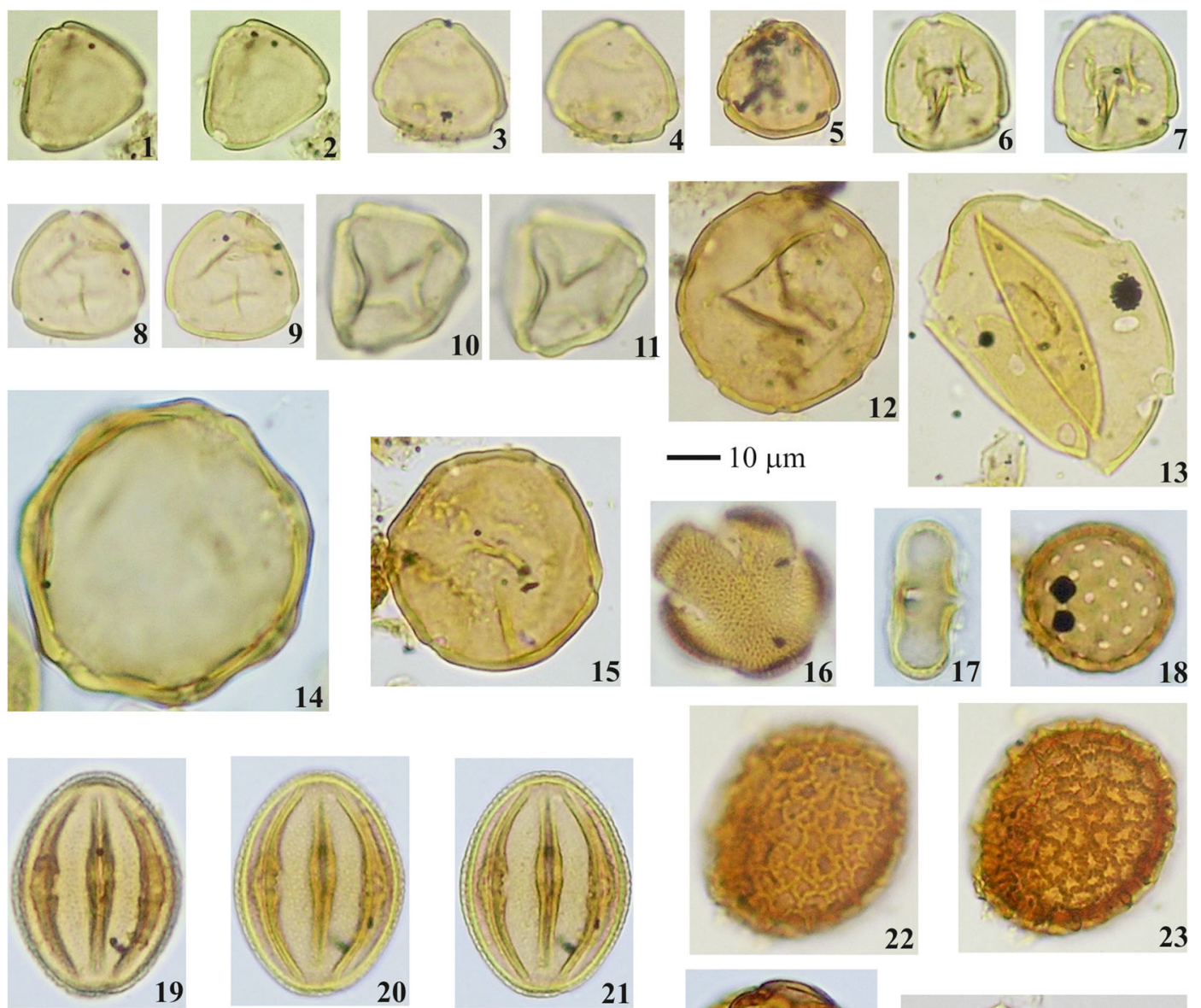

22
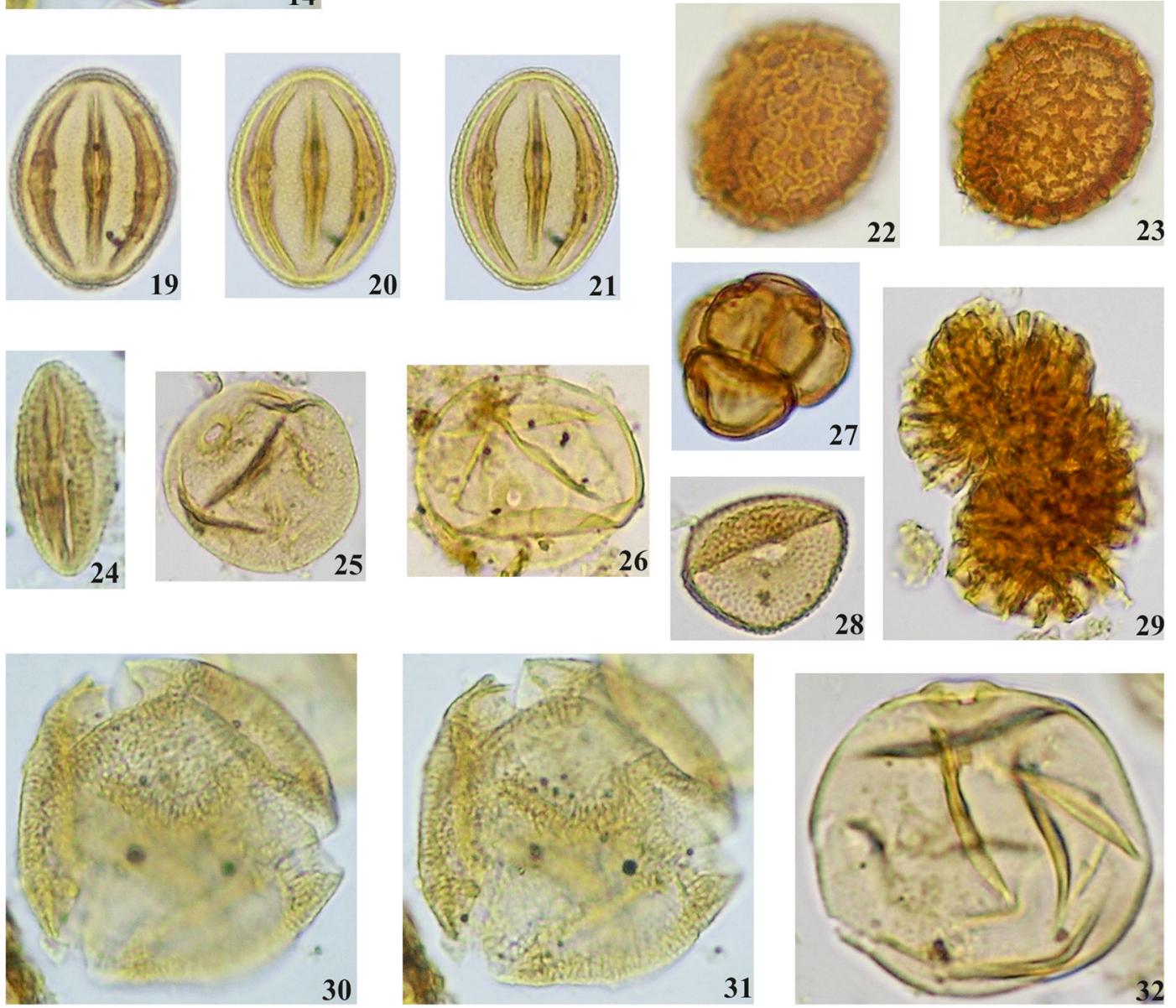

Plate 3 Selected spores and pollen from the late Neogene of the Tundzha Basin. 1-9 - Engelhardia sp. (Morphological variability); 10, 11 - Engelhardia sp. (cf. Engelhardia spicata type); 12 - Juglans sp. 1 (Juglandipollis juglandoides Kohlman-Adamska); 13 - Juglans sp. 2 (Juglandipollis maculosus (Pot.) Kohlman-Adamska); 14 - Pterocarya sp. 1 (cf. Pterocarya pterocarpa (Michx.) Kunth.); 15 - Pterocarya sp. 2 (cf. Pterocarya serrata Schneider); 16 - Lamiaceae; 17 - Apiaceae; 18 - Amaranthaceae: Chenopodioideae; 19-21 - cf. Euphorbia; 22, 23 - Persicaria sp.; 24 - Tricolporopollenites sp.; 25, 26 - Poaceae; 27 - Ericaceae; 28 - Sparganium sp.; 29 - Botryococcus sp.; 30, 31 - Tricolporopollenites sibiricum; 32 - Bambusoideae (Poaceae). Scale bars = $10 \mu m$ 
Herbaceous palaeocenoses have a relatively limited distribution, demonstrated by low percentages of their pollen. This indicates their limited importance for the formation of the vegetation cover compared to the forest palaeocenoses. Their main components were Amaranthaceae: Chenopodioideae, Asteraceae, Caryophyllaceae, Apiaceae, Brassicaceae, Poaceae, Ranunculaceae, Achillea, Artemisia, Aster, Centaurea, Mentha/Salvia, Polygonum, Plantaginaceae, Thalictrum and others. Probably some of them have been involved in the structure of herbs cover in the mesophytic forest communities, while others have occupied open (or erosional) terrains near the basin and the river valleys.

Swamp forests were comparatively limited, as evidenced by the percentage contribution of their components to pollen spectra. Representatives of 'Taxodioid' Cupressaceae and Alnus were predominant in these forests, which are supposed by the slightly higher pollen values found in pollen spectra $(1 \%-2 \%$ to $5 \%-7 \%)$. They were accompanied by species belonging to the genera Glyptostrobus, Sciadopitys, Nyssa, Myrica, Osmunda, Salix, and Cyrillacaeae/Clethraceae, typically represented at around $1 \%$, rarely higher. The presence of pollen from some pollen types characteristic of coastal forests (e.g., Salix, Pterocarya, Platanus, Liquidambar, etc.) can be interpreted as an indication of the distribution of this type of palaeocenoses in the valleys of the inflowing rivers and in the coastal areas. Fraxinus, which in some of the analyzed samples, was recorded with high values compared to other taxa, probably also participated in the composition of riparian forests, swamps or transitional areas with mixed mesophytic forest palaeocenoses. Components of these palaeocenoses were probably the liana species of Vitaceae, Humulus and Hedera.

The spread of swamp forests is likely to be directly related to the water level in the basin. During high water stands of the lake, the diatomite clays were deposited, while at low water stands, the marsh-swampy vegetation was widespread, as precursors of coal seams. The Tundzha
Basin was an extensive graben structure formed in the final stage of the continental collision at the southern edge of the Alpine Orogen. Typically, this type of basins has a similar development, starting with lake-river sedimentation and deposition of conglomerates and sands, gradually passing into clay sedimentation and subsequently swamping and forming thick coal beds covered by lake sediments (Zdravkov et al. 2007). This sequence reflects the drowning of the palaeomire due to high subsidence rates. When subsidence rates decreased, the lake was filled with river-delta sediments. The high number of lignite layers in the Tundzha Basin is the evidence of a relatively low subsidence speed, which allowed the frequent change between lacustrine (diatomaceous and black clays) and swampy environments (lignite).. The high peat content of lignite indicates that swamps were often flooded, and the marsh complex was of the so-called rheolytic marshes (Zdravkov et al. 2007).

The geochemical analysis of the coals showed that lignites originated from coniferous wood, which is significantly more resistant to oxidation processes than that of herbaceous plants and it is better stored (Zdravkov et al. 2007). Probably the main coal precursors were the representatives of Taxodioideae (Taxodium, Glyptostrobus), as in most Miocene lignite basins in Bulgaria.

During the periods of peat accumulation, the (ground)water table was probably not above the peat surface. The basis for such asumption is the complete absence of algal remains and of sapropelic coal (Zdravkov et al. 2007). According to Zdravkov et al. (2007), the vegetation rich in decay-resistant conifers, accompanied by mesophytic broadleaf species, prevailed during these intervals. Due to the lack of samples for pollen analysis from coal beds, this assumption cannot be confirmed or rejected. The studied samples were collected from diatomitic and black clays formed in lake environments. The results of the diatom analysis (Temniskova-Topalova et al. 1996) show that

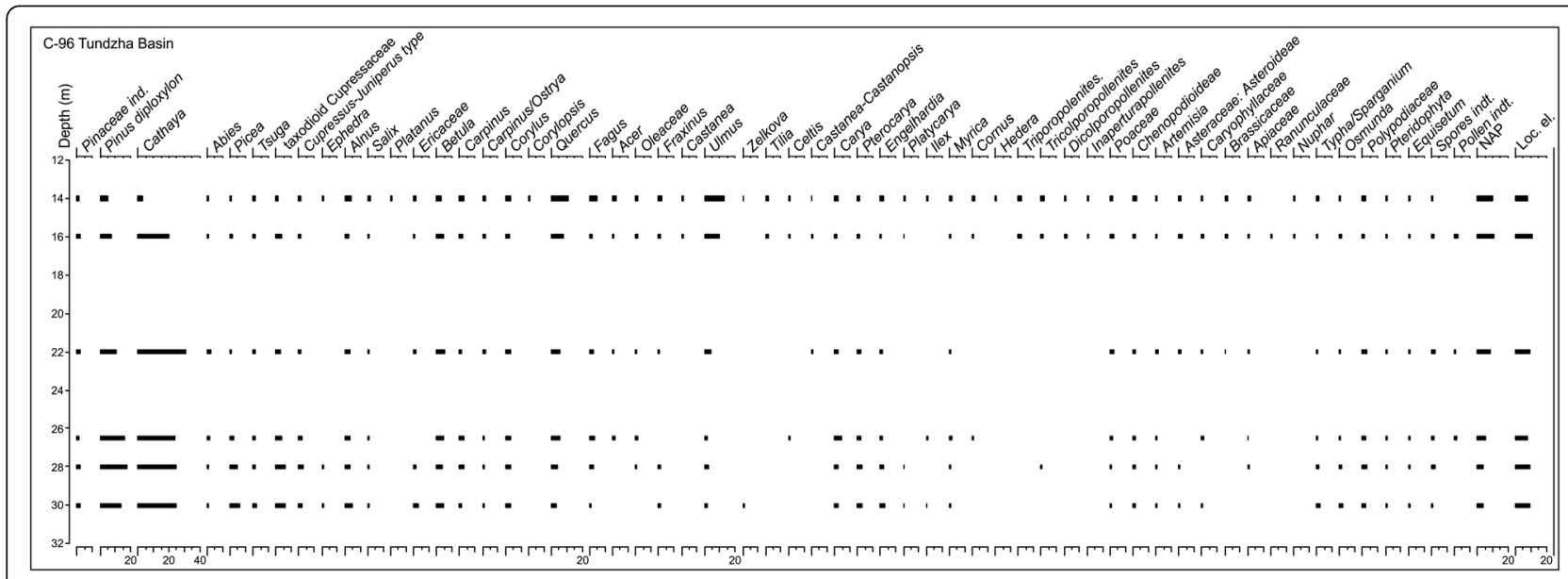

Fig. 4 Spore-pollen percentage diagram of core C-96, Tundzha Basin 


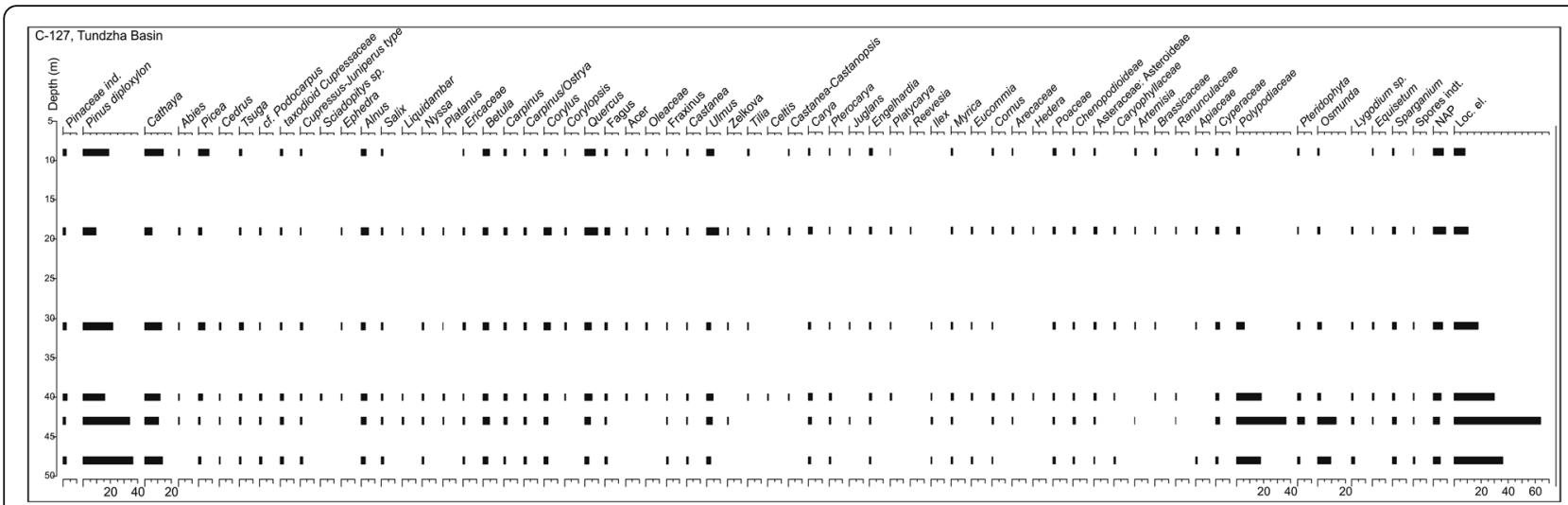

Fig. 5 Spore-pollen percentage diagram of core C-127, Tundzha Basin

during the period of accumulation of diatomaceous clays, the lake had a depth of approximatively $15.0 \mathrm{~m}$. This means that during high water stands in the Tundzha Basin, vast territories flooded and the marshland had been completely submerged. This explains the low participation of swamp palaeocoenoses components, which have been preserved on the outskirts of the lake complex, in conditions suitable for their ecology.

The representatives of aquatic vegetation (euhydrophyte and hygrohydrophyte grasslands) found in the studied pollen spectra are in low quantities and they have a relatively poor species composition. In the open water, typical hydatophytes evolved, such as, in Potamogeton, in Nuphar, and in Nymphaeaceae. In the peripheral areas of the basin, plant communities of helophyite species of Alisma, Persicaria, Typha and Sparganium were developed. The low occurrence of pollen from aquatic plants in the pollen spectra supports the features of the lake basin: rather deep (predominant planktonic species of diatom algae), poorly developed shallow water (suitable for the development of hygrohydrophyte grasslands) and low eutrophicity (Temniskova-Topalova et al. 1996).

The xerophytes (Oleaceae, Celtis, Rhus, Buxus, Pistacia and some grasses) also have a limited distribution occupying possibly eroded or rocky terrains near the lake. The development of this vegetation type was directly related to edaphic and microclimatic factors. The quantitative contribution of sub-xerophytes and xerophytes in pollen spectra does not give reason to assume that they have the character of zonal vegetation.

\section{Climatic analysis of the fossil flora of Tundzha Basin}

The results of the palaeo-climatic analysis of the pollen flora from the studied cores (C-432, C-96, C-127, C-146) obtained using the Coexistence Approach are illustrated in Figs. 11, 12, 13 and 14. The current climate in the Tundzha

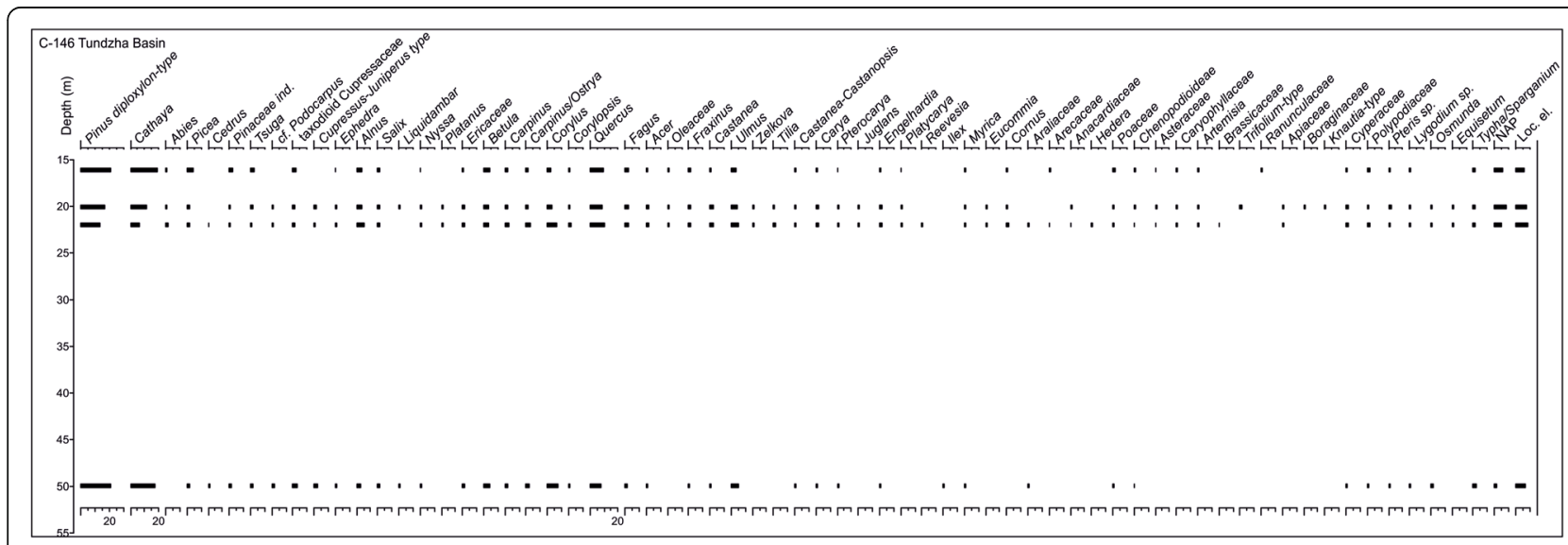

Fig. 6 Spore-pollen percentage diagram of core C-146, Tundzha Basin 


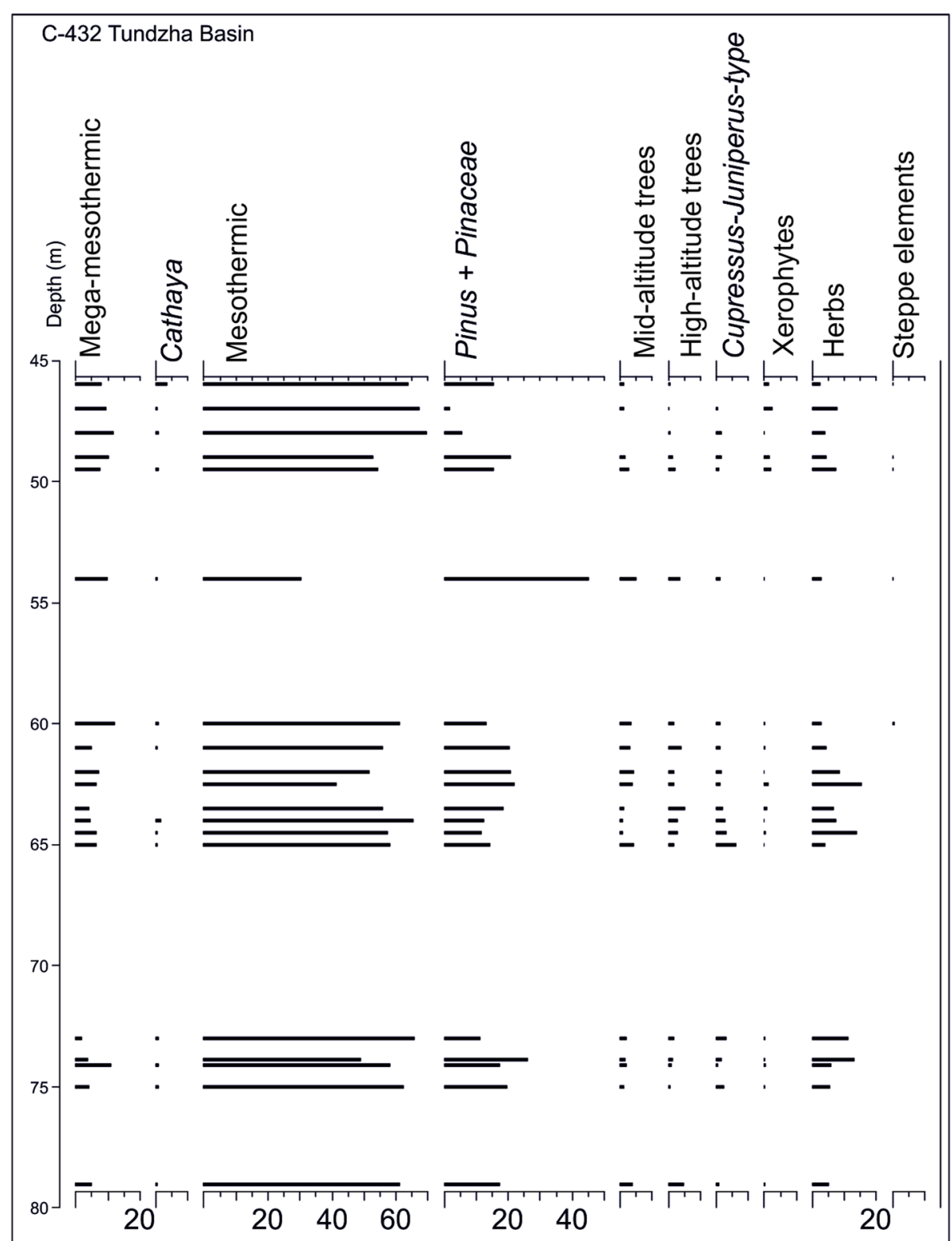

Fig. 7 Synthetic pollen diagram of core C-432, Tundzha Basin

Lowland, Southeast Bulgaria, is characterized by the following climate parameters: the mean annual temperature (MAT) $12.2^{\circ} \mathrm{C}$, the coldest month temperature (CMT) $0.9^{\circ}$ $\mathrm{C}$, the warmest month temperature (WMT) $22.7^{\circ} \mathrm{C}$, and the mean annual precipitation (MAP) $541 \mathrm{~mm}$ according to data from the Yambol meteorological station, located at $143 \mathrm{~m}$ above sea level (Stringmeteo 2006-2009; Velev 1997). For the Elhovo meteorological station (130 m above sea level) the data show: MAT $12.3^{\circ} \mathrm{C}$, CMT $1.1^{\circ} \mathrm{C}$, WMT $22.9^{\circ} \mathrm{C}$, and MAP $545 \mathrm{~mm}$.

The climate reconstruction, based on the palaeoecological data from the Izgrev Member of the Elhovo Formation, shows relatively constant values for observed climate parameters. The lower limit of the coexistence intervals for the mean annual temperature is limited in all the analyzed pollen floras at $15.6^{\circ} \mathrm{C}$. The upper limit is in most cases set at $16.5^{\circ} \mathrm{C}$, only in few cases higher values $\left(18.4{ }^{\circ} \mathrm{C}\right.$ and $\left.19.4{ }^{\circ} \mathrm{C}\right)$ are observed thus forming wider ranges. The average temperature was typically about $16^{\circ} \mathrm{C}$ with few exceptions. These annual temperatures show the relatively high precision of results obtained with the Coexistence Approach. The stability of the data for these parameters and the absence of significant deviations indicate no significant climate change.

Winter temperatures also show relatively constant values without significant changes. The most common 


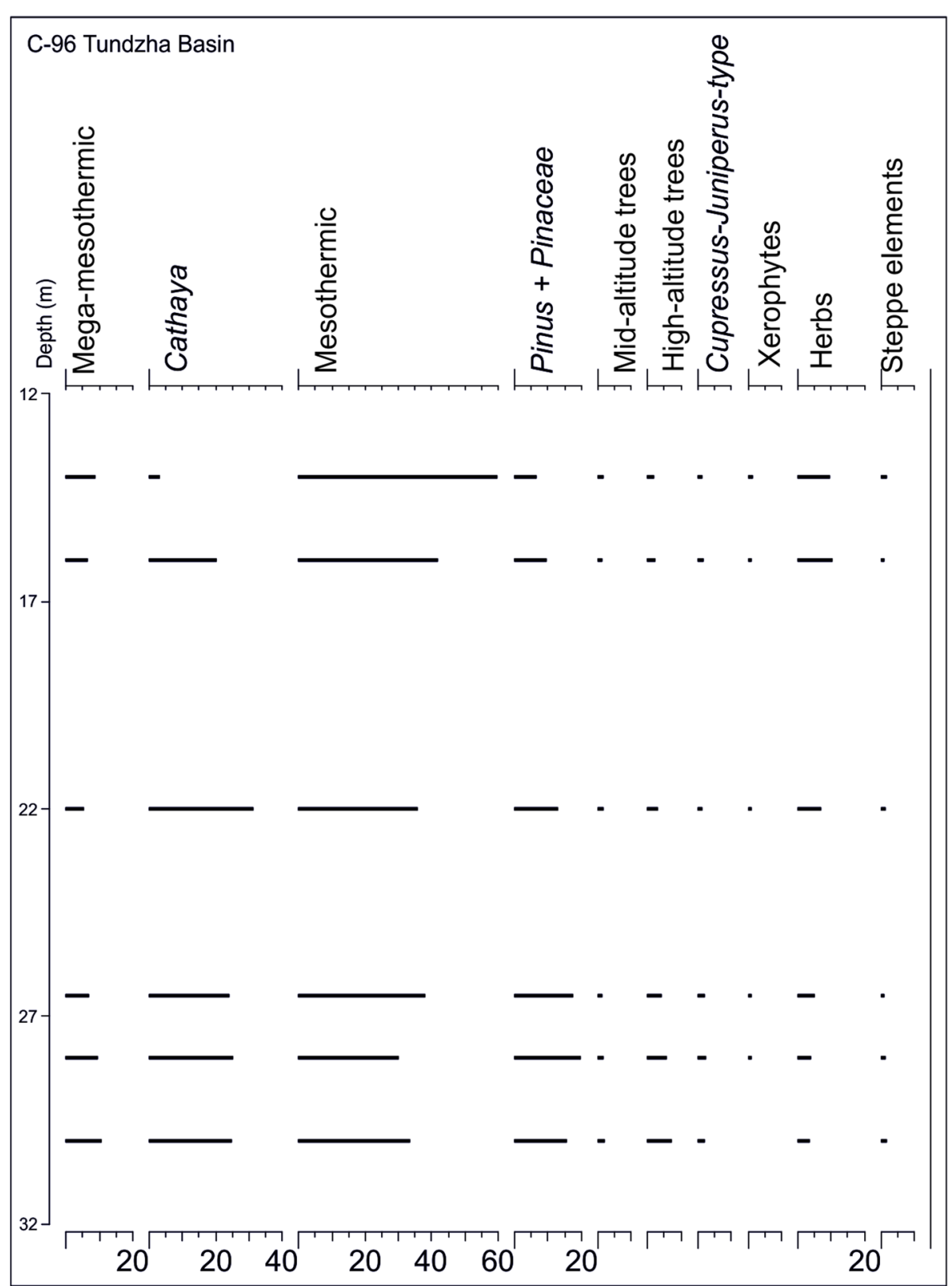

Fig. 8 Synthetic pollen diagram of core C-96, Tundzha Basin

coexistence intervals are $5.0-7.0^{\circ} \mathrm{C}$, and the most common mean values are $6.0^{\circ} \mathrm{C}$. In some cases, the upper limit of calculated cold temperature values indicates higher values and wider ranges, for example, $5.0-8.1{ }^{\circ} \mathrm{C}$ and $5.0-9.6{ }^{\circ} \mathrm{C}$. In the coldest month temperature, the lower limit of intervals is important because low winter temperatures are often a limiting factor for the spread of many plants. The persistence of values above $5.0^{\circ} \mathrm{C}$ indicates a mild and wet winter without extreme minimum temperatures.
Perhaps the wider ranges for the two temperature ratios are related to the incomplete fossil record rather than to a possible climate change. As far as they occur almost in synchronicity in the analyzed pollen flora, a slightly warmer climate with a higher average annual temperature due to higher winter temperatures is not excluded, with less seasonal climate change. The latter assumption is supported by the results obtained for the average temperature of the warmest month. The obtained WMTs are $24.7-27.8^{\circ} \mathrm{C}$ and 


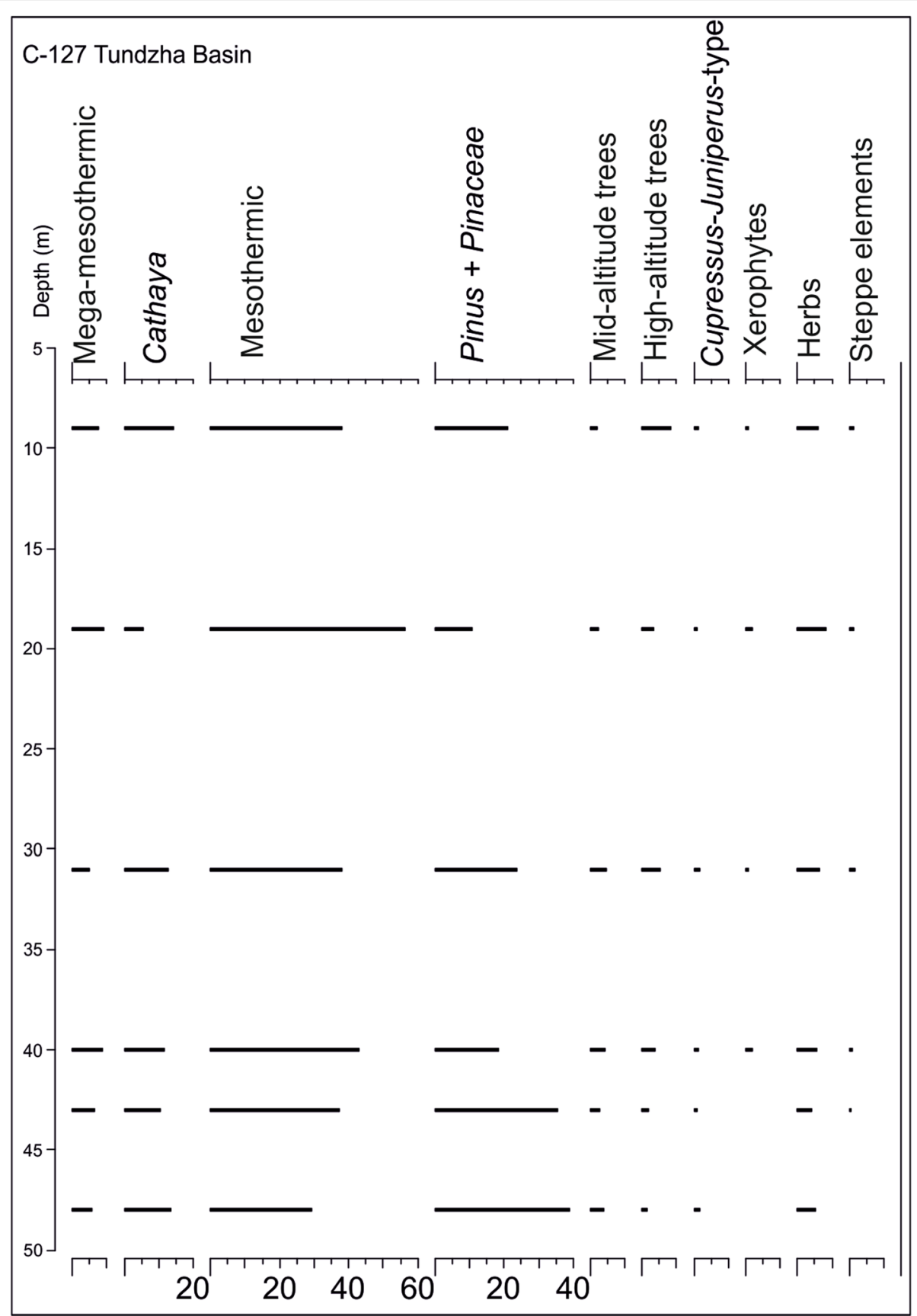

Fig. 9 Synthetic pollen diagram of core C-127, Tundzha Basin

24.7-27.3 ${ }^{\circ} \mathrm{C}$ (with one exception at $61 \mathrm{~m}$; Fig. 11) and the average summer temperatures are in the range of 26.0$26.3^{\circ} \mathrm{C}$. There is no synchronization between wider WMT intervals and the other two indicators - CMT and MAT. This suggests a less pronounced seasonality, related only to a change in winter temperatures.

The mean annual precipitation also does not show drastic deviations. The intervals for annual rainfall are relatively broad ranging from $823 \mathrm{~mm} / \mathrm{m}^{2}$ to $1308 \mathrm{~mm} / \mathrm{m}^{2}$, and the average curve is slightly above $1000 \mathrm{~mm}$.

\section{Discussion}

The dynamics of the pollen quantitative values of the various fossil taxa showed two stages in vegetation development, the boundary between them being established in the pollen spectrum of $60.00 \mathrm{~m}$ in core C-432 (Fig. 3). The representatives of Ulmus and Carya dominate the mesophytic forest communities of the lower part of the profile (LPZ Tu-1). The representatives of Betula, Fagus and Carpinus orientalis/Ostrya also played an important role in the construction of this 


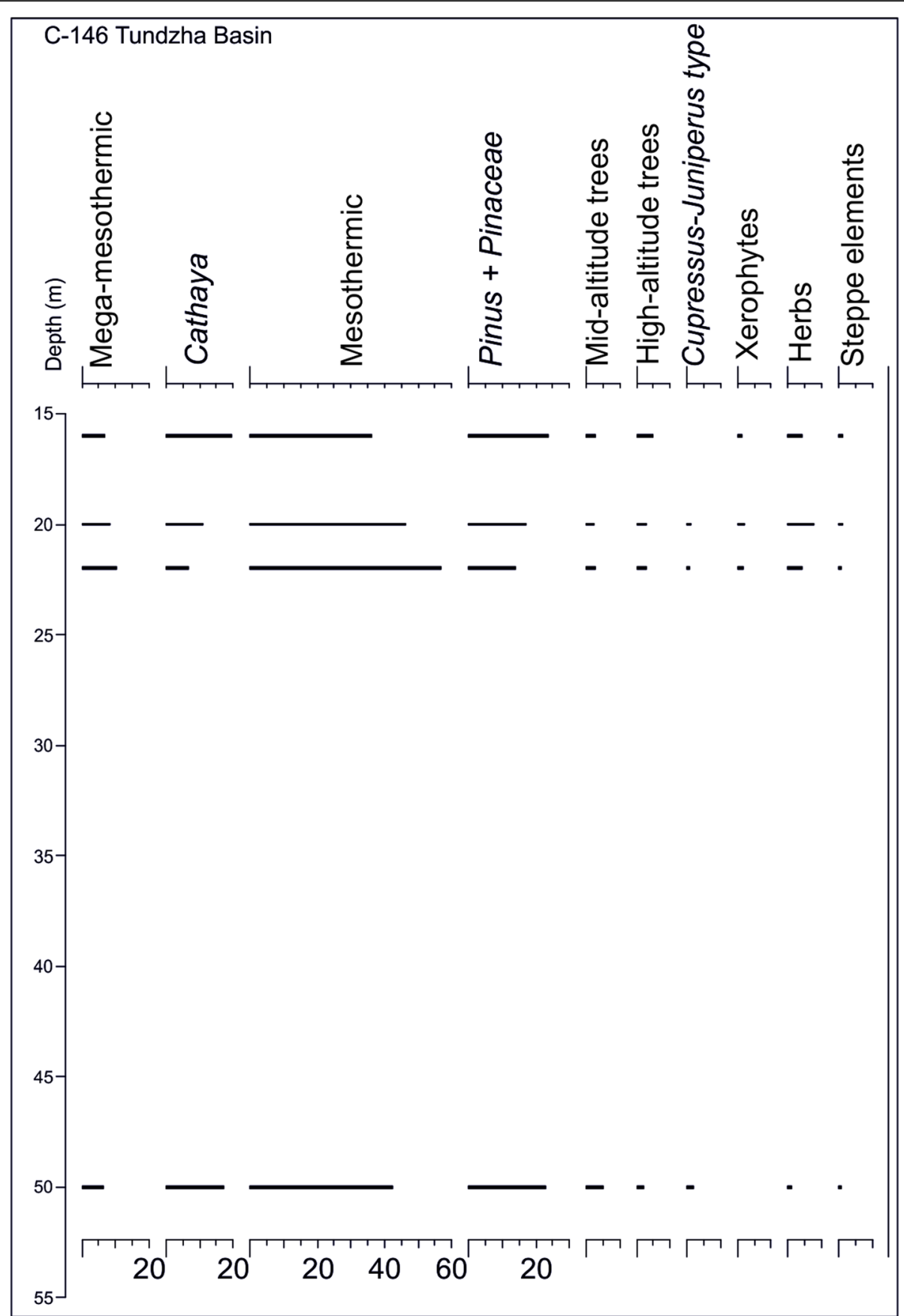

Fig. 10 Synthetic pollen diagram of core C-146, Tundzha Basin

type of palaeocoenosis. The mega-mesothermic elements (Figs. 7, 8, 9 and 10) are represented with lower values and the grasses have a wider distribution reaching a maximum in the range of $64.5-62.5 \mathrm{~m}$ in core C-432. Among the latter, a major role is played by species belonging to the families Asteraceae, Poaceae, and partially Amaranthaceae: Chenopodioideae. Hydrophytic forest palaeocenoses also had a wider spread, and Glyptostrobus was dominant. The representatives of the Nyssa were also important components of the swamp forests. The hydrophytic herbaceous vegetation represented by Typha and Sparganium has also been established. These data testify to the development of the flora in a warm temperate and humid climate.

In the range of $60.0-46.0 \mathrm{~m}$ (LPZ Tu-2) in core C-432 (Fig. 3), a significant change in the composition and 


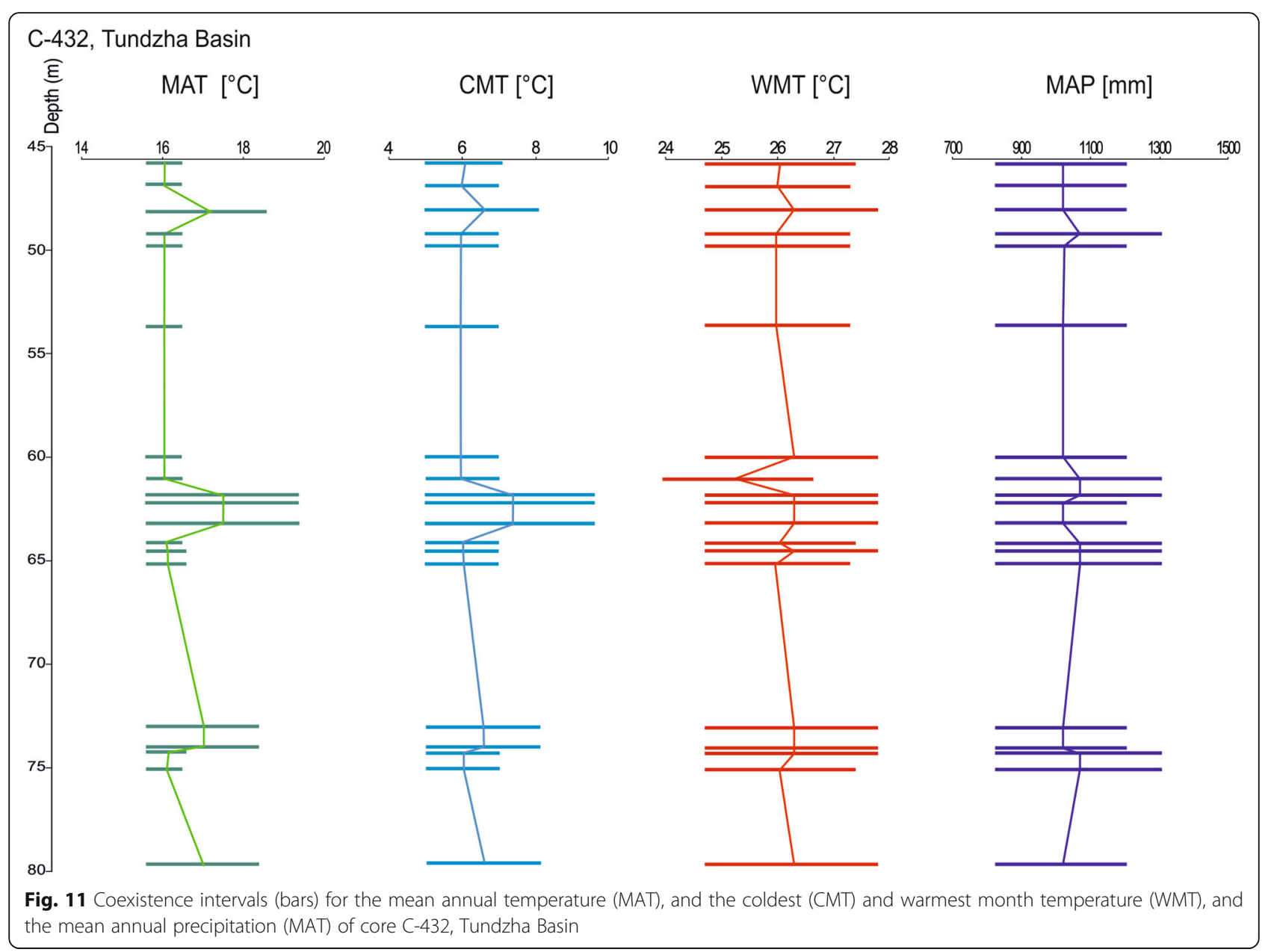

structure of the vegetation was recorded. The change is associated with an increase in Quercus, Fraxinus, Engelhardia, Oleaceae, Buxus, Cyperaceae, Typha, Sparganium and NAP. An interesting fact is that in the diatom flora of core C-432 changes also occur in this interval (Temniskova-Topalova et al. 1996). It is likely that a climate change took place. The beginning of this change is recorded to the top of the profile C-432, and a later result of this change is reflected in the flora from the outcrop SR-1 (see below). The most significant change in the composition of the mesophytic forest communities was a change of dominant taxa - a reduced distribution of Ulmus and Carya is observed, and at the same time, a rapid increase in the values of Quercus and Engelhardia. The participation of Fraxinus pollen, which plays an important role in the construction of riparian forest palaeocenoses, is stronger. The participation of Oleaceae, Buxus and Pistacia in the composition of the vegetation increases in the upper part of the profile. Mega-mesothermic elements (Fig. 7) are presented with higher values, which may indicate warming climate.
The profiles C-96, C-127 and C-146 show a trend towards the reduction of coniferous pollen (Cathaya and Pinus), but the group of mesothermal and subtropical species does not change significantly (Figs. 4, 5 and 6). This change can be correlated with that of the top of core $\mathrm{C}-432$, or it may even be a sequel. The increase in herbaceous pollen at the top of the cores C-96, C-127 and C-146 (Figs. 4 and 7) coincided with some increases in NAP in C-432 and the increased participation of some (sub-) xerophytes in the same range. These data could indicate a certain climate change associated with increased seasonality and the occurrence of drier habitats.

The pollen record from the outcrop SR-1 differs from the four cores. It includes 47 taxa from 30 families (Ivanov et al. 2007c). The fossil macroflora (Palamarev and Bozukov 2004) includes a total of 33 taxa of 16 families of leaf imprints. Based on the composition of the established macro- and micro-flora, the following main plant communities are distinguished: mixed mesophytic forests composed of representatives of Magnolia, Lindera, Daphnogene, Ocotea, Quercus, Carya, Acer, Ulmus, 


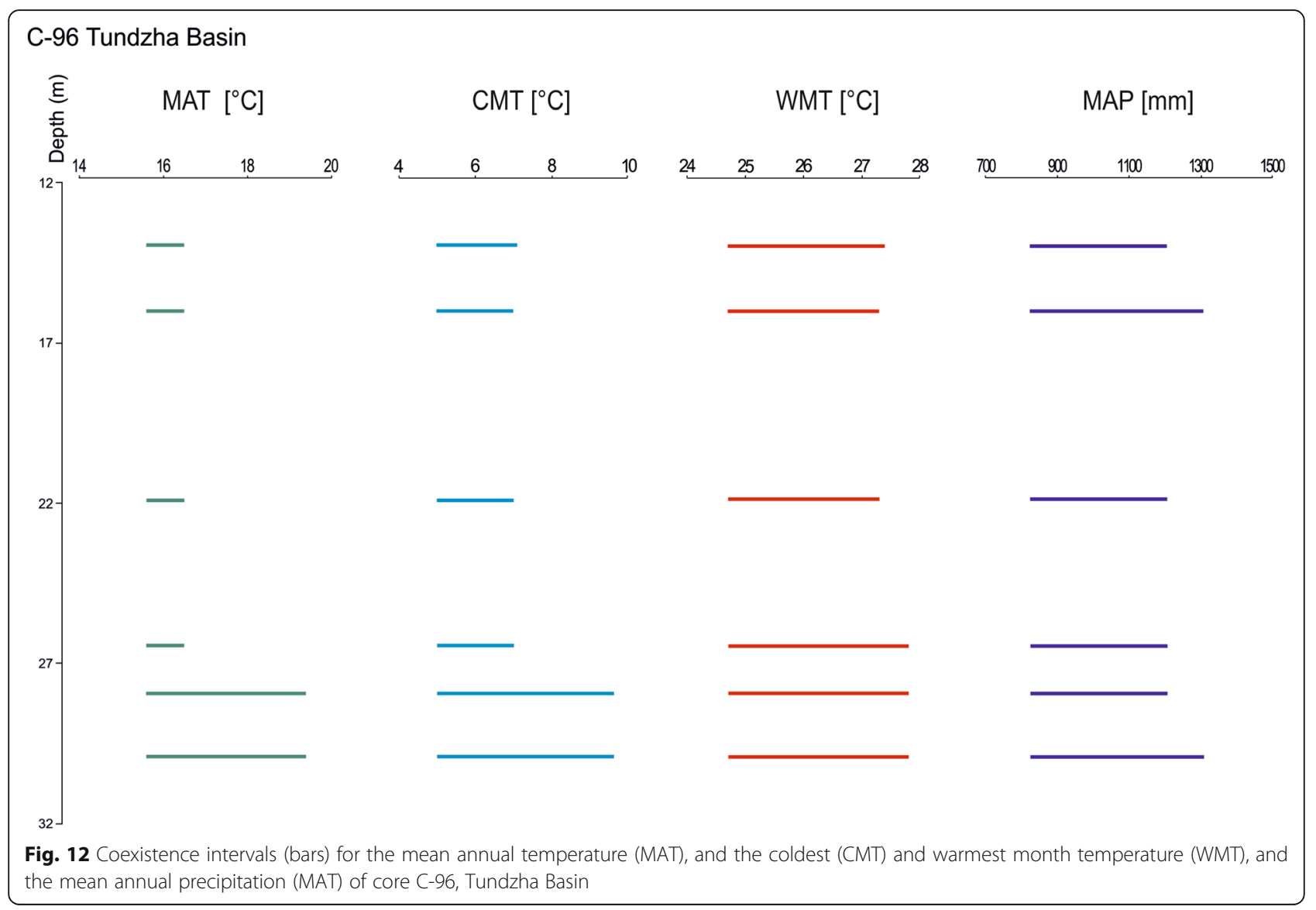

Zelkova, Corylus, Fagus, Castanea, Tilia, Wisteria, etc.; riparian forests involving species of the genera Salix, Populus, Pterocarya, Liquidambar, Alnus, Rhamnus, Nyssa, Myrica, and Bambusoideae; xero-mesophyte tree and shrub communities of Robinia, Arbutus, Paliurus, Pistacia, Parrotia, Oleaceae; herbaceous palaeocenoses composited by the following families and genera: Amaranthaceae: Chenopodioideae, Asteraceae, Artemisia, Centaurea, Plantaginaceae, Caryophyllaceae, Brassicaceae, Apiaceae, Poaceae, Dipsacoideae (Caprifoliaceae); hydrophytic vegetation of Typha, Sparganium, Cyperaceae, Nymphaeaceae.

The representatives of the riparian forests are represented with the greatest number of leaf imprints. This is related, on one hand, to the better storage possibilities (spread around the water basin) and, on another hand, to the relatively limited distribution of mesophytic forest palaeocenoses. In spatial terms, mesophytic forests have been in close contact with riparian and coastal forests, occupying damp habitats in lowered areas of relief without forming a fully developed mesophytic forest belt (Ivanov et al. 2007c). Palynological data also suggest that the mesophytic forests were fragmented, as their representatives have low values and low affinity in pollen spectra.
They differ significantly from the data on the mixed mesophytic forests that existed during the accumulation of the sediments of the Izgrev Member, when they were building the zonal vegetation. During this period of vegetation development, Quercus and Ulmus were the dominants in forest vegetation, with Betula, Carya, Carpinus, Corylus, Acer, Juglans, Engelhardia, Tilia and others. The floristic elements, whose distribution today is bound to temperate climates, but also with some thermophillous taxa, are regular in the pollen record of Engelhardia, Platycarya, Castanea-Castanopsis, Corylopsis (see above). The presence of pollen from Pinus, Tsuga, Cedrus, Keteleeria and Picea implies the presence of mountain forest communities. Their low percentages suggest that the recorded pollen is likely to be a result of a long distant transport, as there were not enough high-mountain systems near the sedimentation site. Xerophytes also played an important role in shaping the palaeolandscape. Their representatives were spread over drier and more eroded terrains, along rocky slopes.

Pollen data suggest a wide spread of grass palaecoenosis $(\mathrm{NAP}=45.8 \%)$. It is quite possible the existence of at least two types of herbaceous communities: mesophytic grasslands inhabiting humid habitats near ponds (wetland 


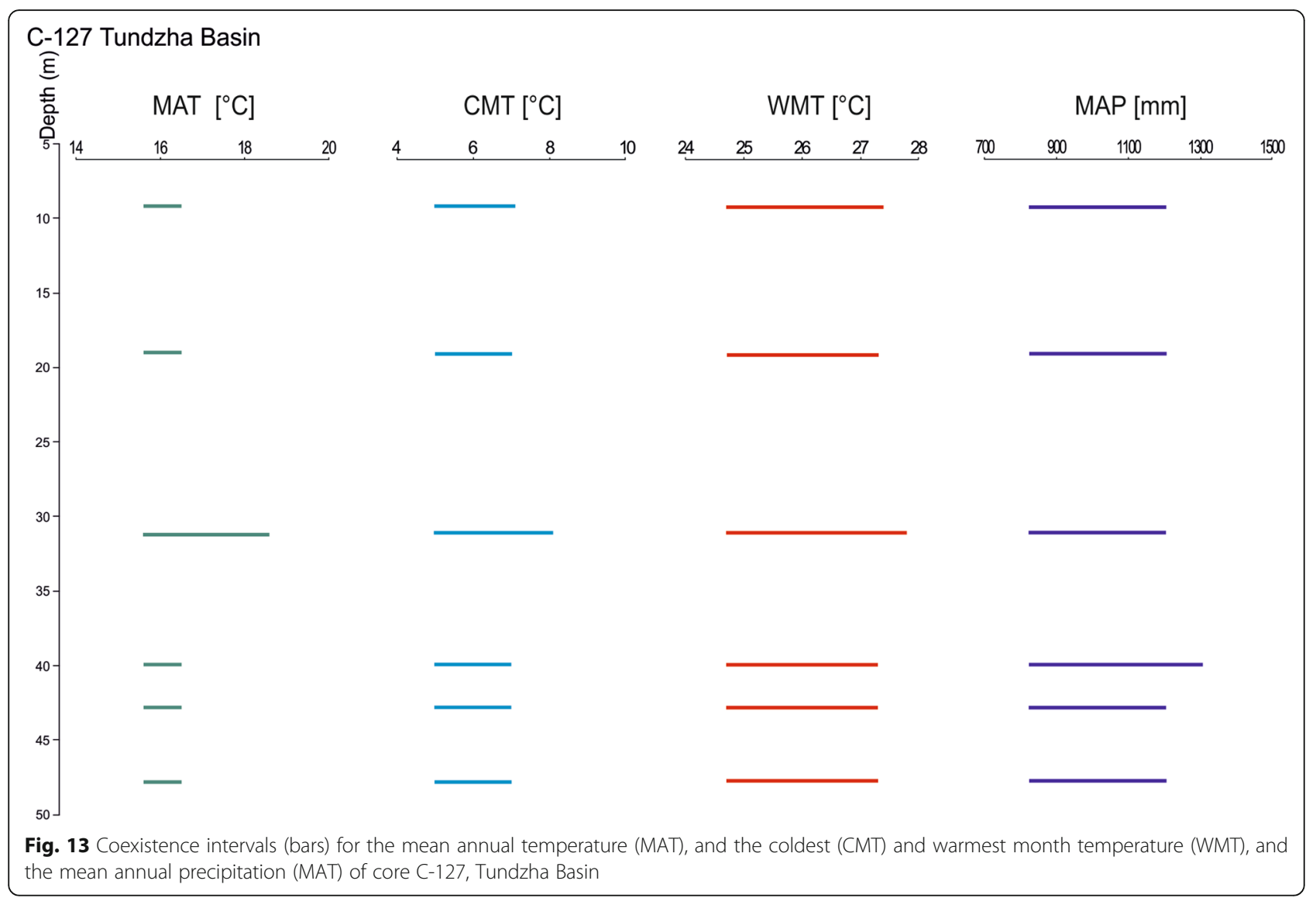

prairies, wet prairies; see Hofmann and Zetter 2005), and more xerophytic herbs spread over drier terrains. As some recent studies on the prevalence of modern pollen and the AP/NAP ratio to their vegetation produce (Favre et al. 2008), small changes in herbs pollen values usually do not take into account real changes in herbaceous vegetation. While the sharp change in the ratio of woody and grassy pollen in favor of the latter is usually a sure indication of open habitats. Palamarev et al. (1999) also testify to the prevalence of xerophytic grasslands, made up of representatives of Polycnemum, Chenopodium, Arenaria and Portulaca, who formed semi-grade species communities on open and eroded terrains.

Popescu (2006) provided palaeoecological data from the Southwest Black Sea Region (DSDP Site 380A) and noted an increase in the grass component and the steppe/forest index (SFI) in the late Miocene-Pliocene. These data correspond to the high NAP values found in this study. A sharp increase and high values of the grass component were also recorded for the upper sequences of the late Miocene sediments of the Karlovo and Staniantsi Basins (Utescher et al. 2009b; Ivanov et al. 2010).

All palaeoclimatic data provided in the current study indicate a warm to subtropical climate with values for all temperatures of about $4{ }^{\circ} \mathrm{C}$ higher than today and with precipitations that were at least $300 \mathrm{~mm}$ higher than today. The climate was steady and stable over the period of sedimentary deposition. This assumption of slight climate change to the top of the profile (LPZ Tu-2), based on the analysis of vegetation changes, finds no confirmation in the climate reconstructions. Perhaps such a change was less than the resolution of the Coexistence Approach, which explains why it was not registered in other palaeoclimate reconstructions.

The climate reconstruction, based on the palaeofloristic data from outcrop SR-1, shows different values for the monitored parameters. The calculations made for the ranges of the individual palaeoclimate values based on the data from fossil macroflora (Ivanov et al. 2007a) show that the annual temperatures were in the range of $14.4-15.8^{\circ} \mathrm{C}$, the winter temperatures were $3.7-5.8^{\circ} \mathrm{C}$, the summer temperatures were $25.6-26.4{ }^{\circ} \mathrm{C}$, and the annual rainfall was in the range of $961-1179 \mathrm{~mm}$. These values are several degrees higher than the current values for the temperatures in the Elhovo-Yambol area, and significantly higher in terms of the amount of precipitation. Calculated values for the same climate parameters, based on palynological data, show wider CA intervals: 


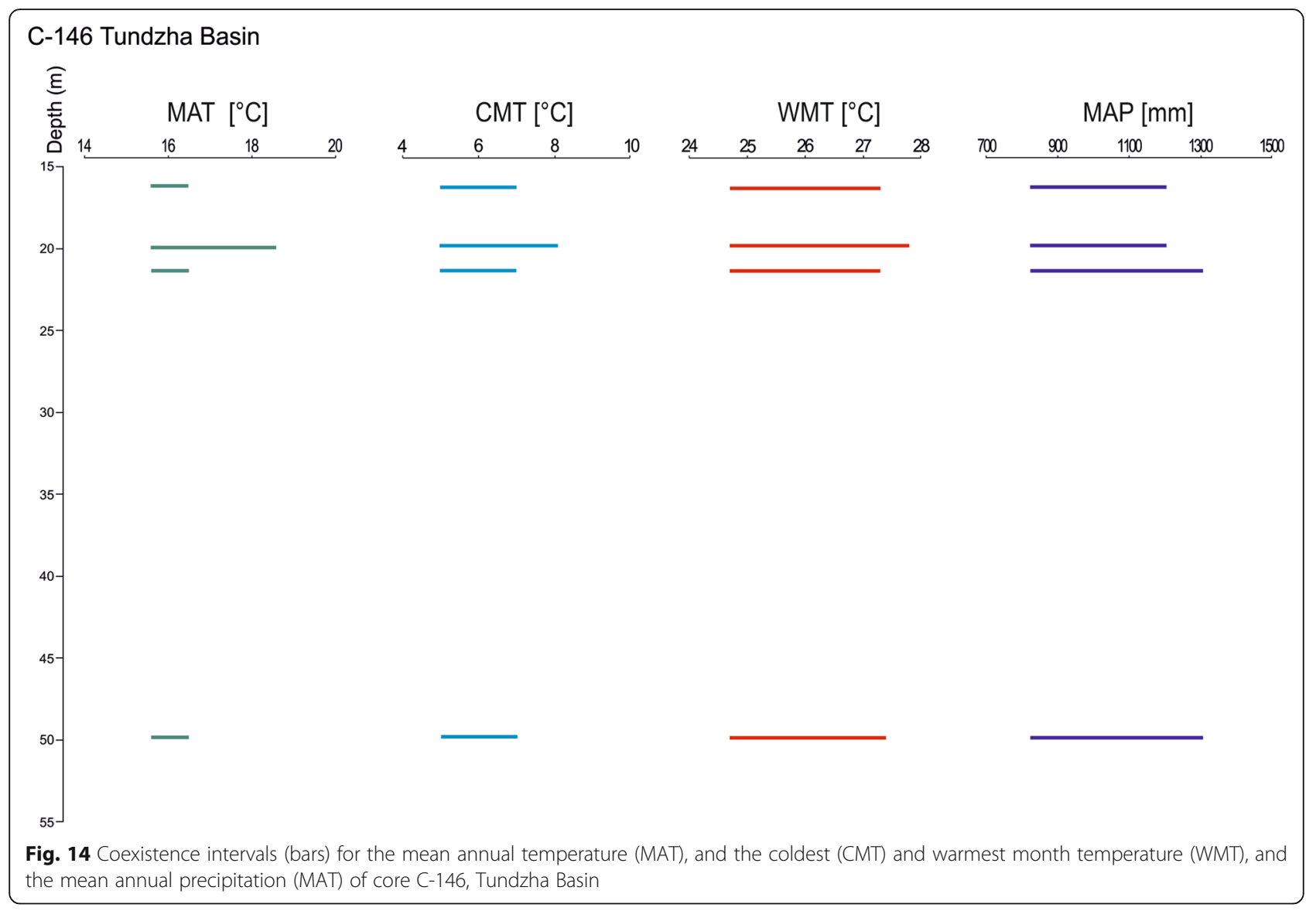

MAT as $13.6-18.4{ }^{\circ} \mathrm{C}$, CMT as $2.4-9.4{ }^{\circ} \mathrm{C}$, WMT as $22.8-26.1^{\circ} \mathrm{C}$, and MAP as $740-1206 \mathrm{~mm}$. The wider coexistence intervals derived from the palynological data are explained by the lower taxonomic resolution of the pollen analysis. The wider annual precipitation interval (740-1206 $\mathrm{mm}$ ) may reflect also the diversity in the climatic conditions of a larger area, and the presence of habitats with a drier character.

The results of the macro- and micro-flora analysis from outcrop SR-1 show a high degree of similarity, which increases the reliability of the resulting palaeoclimate quantification. They are also in line with the palaeoecological analysis of the flora, which implies the development of the vegetation in a temperate climate with a possible dry period in the year. Compared to the results on palaeoclimate, during the deposition of the Izgrev Member, a climate-cooling trend, which is reflected in all temperature parameters, and a lower amount of annual rainfall, is now reported.

\section{Conclusions}

The results from the pollen analysis of the Neogene sediments from the Tundzha Basin include spore and pollen flora permitting to outline the main vegetation palaeocommunities: namely mixed mesophytic forests, swamp forests, communities of aquatic plants, and herbaceous palaeocoenoses. The dominant species in the zonal vegetation were floristic elements growing in warmtemperate to subtropical climate conditions, while thermophillous floristic elements were not well represented. The studied palaeoflora shows a stage in the long-term evolution of the Late Neogene floras in the Balkan Peninsula, connected with the reduction of palaeotropical elements, the dominance of arcto-tertiary taxa in the vegetation structure, and the increased distribution of herbaceous vegetation. Palaeoclimate results obtained with the Coexistance Approach show that the climate in the Tundzha Basin was warm temperate and permanently humid.

The results from the palaeoecological analysis of the flora and the quantitative data on the palaeoclimate recorded from the top of the sediment succession (the outcrop SR-1) show a trend in climate change towards the decline of temperature and of humiditity and a wider distribution of herbaceous vegetation.

\section{Abbreviations}

AP: Arboreal Pollen grains; CA: Coexistence Approach; CAM: Climatic Amplitude Method; CLAMP: Climate Leaf Analysis Multivariate Programme; ELPA: European Leaf Physiognomic Approach.; LMA: Leaf Margin Analysis; NAP: Non-Arboreal Pollen grains 


\section{Acknowledgements}

The authors are grateful to V. Mosbrugger and T. Utescher (Germany) for the kindly provided access to the Palaeoflora database and Climstat software used by us for climate reconstructions. This work is a contribution to the International Network Programe NECLIME (www.neclime.de) and Project B1525/2005 NSF of Bulgaria. The authors are thankfull for the critical reading and the valuable comments of three anonymous peer-reviewers.

\section{Authors' contributions}

DI carried out pollen analysis of core C-432, ML carried out pollen analysis of cores C-96, C-127 and C-146. Interpretetaions, analysis, discussion and conclusions have been done by DI. The design and draft of the manuscript was prepared by DI. All authors read and approved the final manuscript.

\section{Competing interests}

The authors declare that they have no competing interests.

\section{Publisher's Note}

Springer Nature remains neutral with regard to jurisdictional claims in published maps and institutional affiliations.

\section{Received: 19 March 2018 Accepted: 22 October 2018} Published online: 08 January 2019

\section{References}

Akgün, F., M.S. Kayseri, and M.S. Akkiraz. 2007. Palaeoclimatic evolution and vegetational changes during the late Oligocene-Miocene period in Western and Central Anatolia (Turkey). Palaeogeography, Palaeoclimatology, Palaeoecology 253 (1-2): 56-90.

Akkiraz, M.S., M.S. Kayseri, and F. Akgün. 2008. Palaeoecology of coal-bearing Eocene sediments in Central Anatolia (Turkey) based on quantitative palynological data. Turkish Journal of Earth Sciences 17: 317-360.

Alçiçek, H., and G. Jiménez-Moreno. 2013. Late Miocene to Pliocene fluviolacustrine system in Karacasu Basin (SW Anatolia, Turkey): Depositional, palaeogeographic and palaeoclimatic implications. Sedimentary Geology 291: 62-83.

Angelova, D., N. Popov, and M. Mikov. 1991. Stratigraphy of the quaternary sediments in the Tundzha depression. Review Bulgarian Geological Society 52 99-105 (in Bulgarian with English abstract).

Bertini, A. 2002. Palynological evidence of upper Neogene environments in Italy. Acta Universitatis Carolinae, Geologica 46: 15-25.

Bertini, A. 2006. The northern Apennines palynological record as a contribute for the reconstruction of the Messinian palaeoenvironments. Sedimentary Geology 188-189: 235-258.

Biltekin, D., S.-M. Popescu, J.-P. Suc, P. Quézel, G. Jiménez-Moreno, N. Yavuz, and M.N. Çağatay. 2015. Anatolia: A long-time plant refuge area documented by pollen records over the last 23million years. Review Palaeobotany Palynology 215: 1-22.

Bondarenko, O.V., N.I. Blochina, and T. Utescher. 2013. Quantification of Calabrian climate in southern Primory'e, Far East of Russia - An integrative case study using multiple proxies. Palaeogeography, Palaeoclimatology, Palaeoecology 386: 445-458.

Bozukov, V., T. Utescher, and D. Ivanov. 2009. Late Eocene to Early Miocene climate and vegetation of Bulgaria. Review Palaeobotany Palynology 153: 360-374.

Bruch, A.A., S. Fauquette, and A. Bertini. 2002. Quantitative climate reconstructions on Miocene palynofloras of the Velona Basin (Tuscany, Italy). Acta Universitatis Carolinae, Geologica 46: 27-37.

Bruch, A.A., and I. Gabrielyan. 2002. Quantitative data of the Neogene climatic development in Armenia and Nakhichevan. Acta Universitatis Carolinae Geologica 46: 41-48.

Bruch, A.A., and J. Kovar-Eder. 2003. Climatic evaluation of the flora from Oberdorf (Styria, Austria, Early Miocene) based on the coexistence approach. Phytologia Balcanica 9 (2): 175-185.

Bruch, A.A., D. Uhl, and V. Mosbrugger. 2007. Miocene climate in Europe Patterns and evolution: A first synthesis of NECLIME. Palaeogeography, Palaeoclimatology, Palaeoecology 253 (1-2): 1-7.

Bruch, A.A., T. Utescher, and V. Mosbrugger. 2011. Precipitation patterns in the Miocene of Central Europe and the development of continentality. Palaeogeography, Palaeoclimatology, Palaeoecology 304: 202-211.
Bruch, A.A., T. Utescher, V. Mosbrugger, I. Gabrielyan, and D.A. Ivanov. 2006. Late Miocene climate in the circum-alpine realm - A quantitative analysis of terrestrial palaeofloras. Palaeogeography, Palaeoclimatology, Palaeoecology 238: $270-280$.

Bruch, A.A., T. Utescher, C.A. Olivares, N. Dolakova, D. Ivanov, and V. Mosbrugger. 2004. Middle and Late Miocene spatial temperature patterns and gradients in Europe - Preliminary results based on palaeobotanical climate reconstructions. Courier Forschungsinstitut Senckenberg 249: 15-27.

Burchfiel, B.C., R. Nakov, T. Tzankov, and L.H. Royden. 2000. Cenozoic extension in Bulgaria and northern Greece: The northern part of the Aegean extensional regime. In Tectonics and magmatism in Turkey and the surrounding area. Geological Society of London, Special Publication, ed. E. Bozkurt, J.A. Winchester, and J.D.A. Piper, vol. 173, 325-352.

Dragomanov, L., G. Angelov, E. Kojumdgieva, N. Nikolov, and I. Komogorova. 1984. The Neogene in Haskovo district. Palaeontology, Stratigraphy, Lithology 20: 71-75 (in Bulgarian with English abstract).

Durak, S.D.Ü., and M.S. Akkiraz. 2016. Late Oligocene-Early Miocene palaeoecology based on pollen data from the Kalkım-Gönen Basin (Northwest Turkey). Geodinamica Acta 28: 295-310.

Fauquette, S., and A. Bertini. 2003. Quantification of the northern Italy Pliocene climate from pollen data: Evidence for a very peculiar climate pattern. Boreas 32 (2): $361-369$.

Fauquette, S., J. Guiot, and J.-P. Suc. 1998. A method for climatic reconstruction of the Mediterranean Pliocene using pollen data. Palaeogeography, Palaeoclimatology, Palaeoecology 144 (1-2): 183-201.

Fauquette, S., J.P. Suc, A. Bertini, S.-M. Popescu, S. Warny, N. Bachiri Taoufiq, M.-J. Perez Villa, H. Chikhi, N. Feddi, D. Subally, G. Clauzon, and J. Ferrier. 2006. How much did climate force the Messinian salinity crisis? Quantified climatic conditions from pollen records in the Mediterranean region. Palaeogeography, Palaeodlimatology, Palaeoecology 238 (1-4): 281-301.

Fauquette, S., J.-P. Suc, G. Jiménez-Moreno, A. Micheels, A. Jost, E. Favre, N. Bachiri-Taoufiq, A. Bertini, M. Clet-Pellerin, F. Diniz, G. Farjanel, N. Feddi, and Z. Zheng. 2007. Latitudinal climatic gradients in the Western European and Mediterranean regions from the Mid-Miocene (c. $15 \mathrm{Ma}$ ) to the Mid-Pliocene (c. $3.5 \mathrm{Ma}$ ) as quantified from pollen data. The Micropalaeontological Society, Special Publications, The Geological Society, 481-502.

Favre, E., G. Escarguel, J.P. Suc, G. Vidal, and L. Thévenod. 2008. A contribution to deciphering the meaning of AP/NAP with respect to vegetation cover. Review Palaeobotany Palynology 148: 13-35.

Gordon, A., and H.J.B. Birks. 1972. Numerical methods in quaternary palaeoecology. I. Zonation of pollen diagrams. New Phytologist 71 (5): 961-979.

Gradstein, F.M., J.G. Ogg, M.D. Schmitz, and G.M. Ogg. 2012. The geologic time scale. Vol. 1. Boston, Elsevier; 1144 p., https://doi.org/10.1016/B978-0-444-59425-9.01001-5.

Gradstein, F.M., J.G. Ogg, A.G. Smith, W. Bleeker, and L.J. Lourens. 2004. A new geologic time scale, with special reference to Precambrian and Neogene. Episodes 27 (2): 83-100.

Grimm, G.W., J.M. Bouchal, T. Denk, and A. Potts. 2016. Fables and foibles: A critical analysis of the Palaeoflora database and the coexistence approach for palaeoclimate reconstruction. Review Palaeobotany Palynology 200: 211-228.

Grimm, G.W., and T. Denk. 2012. Reliability and resolution of the coexistence approach - A revalidation using modern-day data. Review Palaeobotany Palynology 172: 33-47.

Hofmann, C.-Ch., and R. Zetter. 2005. Reconstruction of different wetland plant habitats of the Pannonian Basin system (Neogene, eastern Austria). Palaios 20: $266-279$

Hristova, V., and D. Ivanov. 2014. Late Miocene vegetation and climate reconstruction based on pollen data from the Sofia Basin (West Bulgaria). Palaeoworld 23 (3-4): 357-369.

Ivanov, D. 2004. Pollen of some exotic plants in the Neogene of Bulgaria. Acta Palaeobotanica 44: 69-77.

Ivanov, D. 2010. Palaeoclimate reconstructions for the Late Miocene in the Southeast Bulgaria using pollen data from the Tundzha Basin. In Scientific Annals, School of Geology, Aristotle University of Thessaloniki, Special, ed. G. Christofides, N. Kantiranis, D.S. Kostopoulus, and A.A. Chatzipetros, vol. 100, 269-278. Thessaloniki, Greece: Proceedings of the XIX CBGA Congress.

Ivanov, D. 2015. Climate and vegetation change during the late Miocene in Southwest Bulgaria based on pollen data from the Sandanski Basin. Review Palaeobotany Palynology 221: 128-137. 
Ivanov, D., A.R. Ashraf, and V. Mosbrugger. 2007a. Late Oligocene and Miocene climate and vegetation in the eastern Paratethys area (Northeast Bulgaria), based on pollen data. Palaeogeography, Palaeoclimatology, Palaeoecology 255 (3-4): 342-360.

Ivanov, D., A.R. Ashraf, V. Mosbrugger, and E. Palamarev. 2002. Palynological evidence for Miocene climate change in the Forecarpathian Basin (central Paratethys, NW Bulgaria). Palaeogeography, Palaeoclimatology, Palaeoecology 178 (1-2): 19-37.

Ivanov, D., A.R. Ashraf, T. Utescher, V. Mosbrugger, and E. Slavomirova. 2007b. Late Miocene vegetation and climate of the Balkan region: Palynology of the Beli Breg Coal Basin sediments. Geologica Carpathica 58 (4): 367-381.

Ivanov, D., V. Bozukov, and E. Koleva-Rekalova. 2007c. Late Miocene flora from SE Bulgaria: Vegetation, landscape and climate reconstruction. Phytologia Balcanica 13 (3): 281-292.

Ivanov, D., N. Djorgova, and E. Slavomirova. 2010. Palynological subdivision of Late Miocene sediments from Karlovo Basin, Central Bulgaria. Phytologia Balcanica 16 (1): 23-42.

Ivanov, D., and M. Lazarova. 2005. Late Miocene flora from Tundzha Basin. Preliminary palynological data. Comptes rendus de l'Academie bulgare des Sciences 58 (7): 799-804.

Ivanov, D., T. Utescher, V. Mosbrugger, S. Syabryaj, D. Djordjević-Milutinović, and S. Molchanoff. 2011. Miocene vegetation and climate dynamics in eastern and central Paratethys (southeastern Europe). Palaeogeography, Palaeoclimatology, Palaeoecology 304: 262-275.

Ivanov, D., and E. Worobiec. 2017. Middle Miocene (Badenian) vegetation and climate dynamics in Bulgaria and Poland based on pollen data. Palaeogeography, Palaeoclimatology, Palaeoecology 467: 83-94.

Jacques, F.M.B., S.-X. Guo, T. Su, Y.-W. Xing, Y.-J. Huang, Y.-S. Liu, D.K. Ferguson, and Z.-K. Zhou. 2011. Quantitative reconstruction of the Late Miocene monsoon climates of Southwest China: A case study of the Lincang flora from Yunnan Province. Palaeogeography, Palaeoclimatology, Palaeoecology 304: 318-327.

Jacques, F.M.B., G.L. Shi, H.M. Li, and W.M. Wang. 2014. An early-middle Eocene Antarctic summer monsoon: Evidence of 'fossil climates'. Gondwana Research 25: $1422-1428$.

Jiménez-Moreno, G. 2006. Progressive substitution of a subtropical forest for a temperate one during the middle Miocene climate cooling in Central Europe according to palynological data from cores Tengelic-2 and Hidas-53 (Pannonian Basin, Hungary). Review Palaeobotany Palynology 142: 1-14.

Jiménez-Moreno, G., H.A. Aziz, F.J. Rodriguez-Tovar, E. Pardo-lguzquiza, and J.-P. Suc. 2007c. Palynological evidence for astronomical forcing in Early Miocene lacustrine deposits from Rubielos de Mora Basin (NE Spain). Palaeogeography, Palaeoclimatology, Palaeoecology 252 (3): 601-616.

Jiménez-Moreno, G., A. de Leeuw, O. Mandic, M. Harzhauser, D. Pavelic, W. Krijgsman, and A. Vranjkovic. 2009. Integrated stratigraphy of the Early Miocene lacustrine deposits of Pag Island (SW Croatia): Palaeovegetation and environmental changes in the Dinaride Lake system. Palaeogeography, Palaeoclimatology, Palaeoecology 280: 193-206.

Jiménez-Moreno, G., S. Fauquette, and J.-P. Suc. 2008a. Vegetation, climate and palaeoaltitude reconstructions of the eastern Alps during the Miocene based on pollen records from Austria, Central Europe. Journal of Biogeography 35 (9): 1638-1649.

Jiménez-Moreno, G., S. Fauquette, J.-P. Suc, and H.A. Aziz. 2007a. Early Miocene repetitive vegetation and climatic changes in the lacustrine deposits of the Rubielos de Mora Basin (Teruel, NE Spain). Palaeogeography, Palaeoclimatology, Palaeoecology 250 (1): 101-113.

Jiménez-Moreno, G., O. Mandic, M. Harzhauser, D. Pavelic, and A. Vranjkovic. 2008b. Vegetation and climate dynamics during the early middle Miocene from Lake Sinj (Dinaride Lake system, SE Croatia). Review Palaeobotany Palynology 152 (3-4): 270-278.

Jiménez-Moreno, G., S.-M. Popescu, D. Ivanov, and J.-P. Suc. 2007b. Neogene flora, vegetation and climate dynamics in southeastern Europe and the northeastern Mediterranean. In Deep-Time Perspectives on Climate Change: Marrying the Signal from Computer Models and Biological Proxies, ed. M. Williams, A.M. Haywood, F.J. Gregory, and D.N. Schmidt, 503-516. London: The Micropalaeontological society, geological society, Special Publications.

Jiménez-Moreno, G., F.J. Rodriguez-Tovar, E. Pardo-Iguzquiza, S. Fauquette, J.-P. Suc, and P. Muller. 2005. High-resolution palynological analysis in late earlymiddle Miocene core from the Pannonian Basin, Hungary: Climatic changes, astronomical forcing and eustatic fluctuations in the central Paratethys. Palaeogeography, Palaeoclimatology, Palaeoecology 216 (1): 73-97.
Jiménez-Moreno, G., and J.-P. Suc. 2007. Middle Miocene latitudinal climatic gradient in Western Europe: Evidence from pollen records. Palaeogeography, Palaeoclimatology, Palaeoecology 253: 208-225.

Kayseri-Özer, M.S. 2017. Cenozoic vegetation and climate change in Anatolia - A study based on the IPR-vegetation analysis. Palaeogeography, Palaeodimatology, Palaeoecology 467: 37-68.

Kayseri-Özer, M.S., L. Karadenizli, F. Akgün, N. Oyal, G. Saraç, \$̧. Şen, C. Tunoğlu, and A. Tuncer. 2017. Palaeoclimatic and palaeoenvironmental interpretations of the late Oligocene, Late Miocene-early Pliocene in the Çankırı-Çorum Basin. Palaeogeography, Palaeoclimatology, Palaeoecology 467: 16-36.

Kojumdgieva, E., S. Stojkov, and S. Markova. 1984. Lithostratigraphy of the Neogene sediments in Tundzha Basin. Review of Bulgarian Geological Society 45 (3): 287-295 (in Bulgarian with English abstract).

Mai, D., and E. Palamarev. 1997. Neue paläofloristische Funde aus kontinentalen und brackichen Tertiärformationen in Bulgarien. Feddes Repertorium 108: 481-506.

Meulenkamp, J.E., M. Kovac, and I. Cicha. 1996. On late Oligocene to Pliocene depocentre migrations and the evolution of the Carpathian-Pannonian system. Tectonophysics 266: 301-317.

Meulenkamp, J.E., and W. Sissingh. 2003. Tertiary palaeogeography and tectonostratigraphic evolution of the Northern and Southern Peri-Tethys platforms and the intermediate domains of the African-Eurasian convergent plate boundary zone. Palaeogeography, Palaeoclimatology, Palaeoecology 196: 209-228.

Mosbrugger, V., and T. Utescher. 1997. The coexistence approach - A method for quantitative reconstructions of tertiary terrestrial palaeoclimate data using plant fossils. Palaeogeography, Palaeoclimatology, Palaeoecology 134 (1-4): 61-86.

Mosbrugger, V., T. Utescher, and D.L. Dilcher. 2005. Cenozoic continental climatic evolution of Central Europe. Proceedings of the National Academy of Sciences 102 (42): 14964-14969.

Nakov, R., B.C. Burchfiel, T. Tzankov, and L.H. Royden. 2001. Late Miocene to recent sedimentary basins of Bulgaria. Geological Society of America Map and Chart Series, MCHO 88: 1-28.

Nikolov, I. 1985. Catalogue of the localities of tertiary mammals in Bulgaria. Palaeontology, Stratigraphy and Litholology 21: 43-62.

Nix, H. 1982. Environmental determinants of biogeography and evolution in Terra Australis. In Evolution of the Flora and fauna of arid Australia, ed. W.R. Barker and P.J.M. Greenslade, 47-66. Frewville: Peacock Publishing.

Palamarev, E. 1989. Paleobotanical evidences of the tertiary history and origin of the Mediterranean sclerophyll dendroflora. Plant Systematics and Evolution 162: 93-107.

Palamarev, E. 1990. Grundzüge der paläofloristischen Paläosukzessionen im Spätmiozän (Sarmatien-Pontien) Bulgariens. In Proceedings of the symposium Palaeofloristic and Palaeoclimatic changes in the cretaceous and tertiary, Prague 1989, ed. E. Knobloch and Z. Kvaček, 257-263. Prague: Geological Survey.

Palamarev, E., and V. Bozukov. 2004. The macroflora of Neogene sediments in the Elhovo formation (Southeast Bulgaria). Phytologia Balcanica 10 (2-3): 131-146.

Palamarev, E., and D. Ivanov. 1998. Über einige Besonderheiten der tertiären Floren in Bulgarien und ihre Bedeutung für die Entwicklungsgeschichte der Pflanzenwelt in Europa. Acta Palaeobotanica 38: 147-165.

Palamarev, E., and D. Ivanov. 2001. Charakterzüge der Vegetation des Sarmatien (Mittel-bis Obermiozän) im südlichen Teil des Dazischen Beckens (Südost Europa). Palaeontographica 259: 209-220.

Palamarev, E., and D. Ivanov. 2004. Badenian vegetation of Bulgaria: Biodiversity, palaeoecology and palaeoclimate. Courier Forschungsinstitut Senckenberg 249: 63-69.

Palamarev, E., D. Ivanov, and V. Bozukov. 1999. Paläoflorenkomplexe im Zentralbalkanischen Raum und ihre Entwicklungsgeschichte von der Wende Oligozän/Miozän bis ins Villafranchien. Flora Tertiaria Mediterranea VI (5): 1-95.

Popescu, S.-M. 2006. Late Miocene and early Pliocene environments in the southwestern Black Sea region from high-resolution palynology of DSDP site 380A (leg 42B). Palaeogeography, Palaeoclimatology, Palaeoecology 238 (1-4): 64-77.

Popov, S.V., I.G. Shcherba, L.B. Ilyina, L.A. Nevesskaya, N.P. Paramonova, S.O. Khondkarian, and I. Magyar. 2006. Late Miocene to Pliocene palaeogeography of the Paratethys and its relation to the Mediterranean. Palaeogeography, Palaeoclimatology, Palaeoecology 238: 91-106.

Pross, J., S. Klotz, and V. Mosbrugger. 2000. Reconstructing palaeotemperatures for the early and middle Pleistocene using the mutual climatic range method based on plant fossils. Quaternary Science Reviews 19: 1785-1799. 
Rögl, F. 1998. Palaeogeographic considerations for Mediterranean and paratethys seaways (Oligocene to Miocene). Annalen des Naturhistorischen Museums in Wien 99: 279-310.

Rögl, F. 1999. Mediterranean and paratethys. Facts and hypotheses of an Oligocene to Miocene paleogeography (short overview). Geologica Carpathica 50: 339-349.

Savov, S. 1983. Construction of the Elhovo structural decline. Review Bulgarian Geological Society 44 (3): 326-331 (in Bulgarian with English abstract).

Stringmeteo, 2006-2009. Climate data for reference Bulgarian stations (19611990, Monthly weather-fore-cast of NIMH). https://www.stringmeteo.com/ synop/bg_climate.php?m1=7\&m2=8\&station (in Bulgarian). Last accessed: 28 Nov 2018.

Suc, J.-P. 1984. Origin and evolution of the Mediterranean vegetation and climate in Europe. Nature 307: 429-432.

Temniskova-Topalova, D., D.A. Ivanov, and E. Popova. 1996. Diatom analysis on Neogene sediments from the Elhovo Basin in South Bulgaria. Geologica Carpathica 47 (5): 289-300.

Temniskova-Topalova, D., and N. Ognjanova-Rumenova. 1997. Description, comparison and biostratigraphy of the nonmarine Neogene diatom floras from southern Bulgaria. Geologica Balcanica 27 (1-2): 57-81.

Traiser, C., S. Klotz, D. Uhl, and V. Mosbrugger. 2005. Environmental signals from leaves - A physiognomic analysis of European vegetation. New Phytologist 166: 465-484.

Traiser, C., D. Uhl, S. Klotz, and V. Mosbrugger. 2007. Leaf physiognomy and palaeoenvironmental estimates - An alternative technique based on an European calibration. Acta Palaeobotanica 47 (1): 181-201.

Uhl, D., A. Bruch, C. Traiser, and S. Klotz. 2006. Palaeoclimate estimates for the middle Miocene Schrotzburg flora (S Germany): A multi-method approach. International Journal of Earth Sciences 95 (6): 1071-1085.

Uhl, D., S. Klotz, C. Traiser, C. Thiel, T. Utescher, E. Kowalski, and D.L. Dilcher 2007b. Cenozoic paleotemperatures and leaf physiognomy - A European perspective. Palaeogeography, Palaeoclimatology, Palaeoecology 248: 24-31.

Uhl, D., V. Mosbrugger, A. Bruch, and T. Utescher. 2003. Reconstructing palaeotemperatures using leaf floras - Case studies for a comparison of leaf margin analysis and the coexistence approach. Review Palaeobotany Palynology 126: 49-64.

Uhl, D., C. Traiser, U. Griesser, and T. Denk. 2007a. Fossil leaves as palaeoclimate proxies in the Palaeogene of Spitsbergen (Svalbard). Acta Palaeobotanica 47 (1): 89-107.

Utescher, T., M. Böhme, T. Hickler, Y. Liu, V. Mosbrugger, and F. Portmann. 2013. Continental climate and vegetation patterns in North America and Western Eurasia before and after the closure of the central American seaway. In: GSA 125th anniversary annual meeting, Geological Society of America, Abstracts with Programs, Denver 45, 7, 302.

Utescher, T., M. Böhme, and V. Mosbrugger. 2011a. The Neogene of Eurasia: Spatial gradients and temporal trends - The second synthesis of NECLIME Palaeogeography, Palaeoclimatology, Palaeoecology 304: 196-201.

Utescher, T., O.V. Bondarenko, and V. Mosbrugger. 2015. The Cenozoic cooling Continental signals from the Atlantic and Pacific side of Eurasia. Earth and Planetary Science Letters 415: 121-133.

Utescher, T., A.A. Bruch, B. Erdei, L. François, D. Ivanov, F.M.B. Jacques, A.K. Kern, Y. Liu, V. Mosbrugger, and R.A. Spicer. 2014. The coexistence approach Theoretical background and practical considerations of using plant fossils for climate quantification. Palaeogeography, Palaeoclimatology, Palaeoecology 410: 58-73.

Utescher, T., A.A. Bruch, A. Micheels, V. Mosbrugger, and S. Popova. 2011b. Cenozoic climate gradients in Eurasia - A palaeo-perspective on future climate change? Palaeogeography, Palaeoclimatology, Palaeoecology 304: 351-358.

Utescher, T., D. Djordjevic-Milutinovic, A. Bruch, and V. Mosbrugger. 2007 Palaeoclimate and vegetation change in Serbia during the last $30 \mathrm{Ma}$ Palaeogeography, Palaeoclimatology, Palaeoecology 253 (1-2): 141-152.

Utescher, T., D. Ivanov, M. Harzhauser, V. Bozukov, A.R. Ashraf, C. Rolf, M. Urbat, and V. Mosbrugger. 2009b. Cyclic climate and vegetation change in the late Miocene of Western Bulgaria. Palaeogeography, Palaeoclimatology, Palaeoecology 272 (1-2): 99-114.

Utescher, T., and V. Mosbrugger. 1990-2018. The Palaeoflora Database. http:// www.palaeoflora.de.

Utescher, T., V. Mosbrugger, D. Ivanov, and D.L. Dilcher. 2009a. Present-day climatic equivalents of European Cenozoic climates. Earth and Planetary Science Letters 284: 544-552.
Velev, S. 1997. Contemporary air temperature and precipitation fluctuations in Bulgaria. In Geography of Bulgaria, ed. M. Jordanova and D. Donchev, 145150. Sofia: Publishing House Bulgarian Academy Sciences (in Bulgarian with English abstract).

Wilf, P. 1997. When are leaves good thermometers? A new case for leaf margin analysis. Paleobiology 23: 373-390.

Wolfe, J.A. 1993. A method of obtaining climatic parameters from leaf assemblages. US Geological Survey Bulletin 2040: 1-71.

Xing, Y.-W., T. Utescher, F.M.B. Jacques, S. Tao, Y.-S. Liu, Y.-J. Huang, and Z.-K. Zhou. 2012. Palaeoclimatic estimation reveals a weak winter monsoon in southwestern China during the late Miocene: Evidence from plant macrofossils. Palaeogeography, Palaeoclimatology, Palaeoecology 358-360: 19-26.

Yang, J., Y.-F. Wang, R.A. Spicer, V. Mosbrugger, C.-S. Li, and Q.-G. Sun. 2007 Climatic reconstruction at the Miocene Shanwang basin, China, using leaf margin analysis, CLAMP, coexistence approach, and overlapping distribution analysis. American Journal of Botany 94: 599-608.

Yavuz, N., G. Culha, S.S. Demirer, T. Utescher, and A. Aydın. 2017. Pollen, ostracod and stable isotope records of palaeoenvironment and climate: Upper Miocene and Pliocene of the Çankırı basin (Central Anatolia, Turkey). Palaeogeography, Palaeoclimatology, Palaeoecology 467: 149-165.

Zachos, J., M. Pagani, L. Sloan, E. Thomas, and K. Billups. 2001. Trends, rhythms, and aberrations in global climate 65 Ma to present. Science 292 (5517): 686-693.

Zdravkov, A., I. Kostova, and J. Kortenski. 2007. Properties and depositional environment of the Neogene Elhovo lignite, Bulgaria. International Journal of Coal Geology 71 (4): 488-504.

\section{Submit your manuscript to a SpringerOpen ${ }^{\circ}$ journal and benefit from:}

- Convenient online submission

- Rigorous peer review

- Open access: articles freely available online

- High visibility within the field

- Retaining the copyright to your article

Submit your next manuscript at $>$ springeropen.com 